\title{
Characterization of Conjugates between $\alpha$-Lactalbumin and Benzyl Isothiocyanate-Effects on Molecular Structure and Proteolytic Stability
}

\author{
Jenny Spöttel ${ }^{1}$, Johannes Brockelt ${ }^{1}\left(\mathbb{D}\right.$, Sven Falke ${ }^{2}$ and Sascha Rohn ${ }^{1,3, *}$ (D) \\ 1 Institute of Food Chemistry, Hamburg School of Food Science, University of Hamburg, Grindelallee 117, \\ 20146 Hamburg, Germany; jenny.spoettel@chemie.uni-hamburg.de (J.S.); \\ johannes.brockelt@chemie.uni-hamburg.de (J.B.) \\ 2 Laboratory for Structural Biology of Infection and Inflammation, Institute of Biochemistry and Molecular \\ Biology, University of Hamburg, Notkestr. 85, 22603 Hamburg, Germany; falke@chemie.uni-hamburg.de \\ 3 Department of Food Chemistry and Analysis, Institute of Food Technology and Food Chemistry, Technische \\ Universität Berlin, TIB 4/3-1, Gustav-Meyer-Allee 25, 13355 Berlin, Germany \\ * Correspondence: rohn@tu-berlin.de; Tel.: +49-30-314-72583
}

Citation: Spöttel, J.; Brockelt, J.; Falke, S.; Rohn, S. Characterization of Conjugates between $\alpha$-Lactalbumin and Benzyl Isothiocyanate-Effects on Molecular Structure and Proteolytic Stability. Molecules 2021, 26, 6247. https://doi.org/10.3390/ molecules26206247

Academic Editor: Farid Chemat

Received: 28 September 2021

Accepted: 12 October 2021

Published: 15 October 2021

Publisher's Note: MDPI stays neutral with regard to jurisdictional claims in published maps and institutional affiliations.

Copyright: (c) 2021 by the authors. Licensee MDPI, Basel, Switzerland. This article is an open access article distributed under the terms and conditions of the Creative Commons Attribution (CC BY) license (https:// creativecommons.org/licenses/by/ $4.0 /)$.

\begin{abstract}
In complex foods, bioactive secondary plant metabolites (SPM) can bind to food proteins Especially when being covalently bound, such modifications can alter the structure and, thus, the functional and biological properties of the proteins. Additionally, the bioactivity of the SPM can be affected as well. Consequently, knowledge of the influence of chemical modifications on these properties is particularly important for food processing, food safety, and nutritional physiology. As a model, the molecular structure of conjugates between the bioactive metabolite benzyl isothiocyanate (BITC, a hydrolysis product of the glucosinolate glucotropaeolin) and the whey protein $\alpha$-lactalbumin $(\alpha$-LA) was investigated using circular dichroism spectroscopy, anilino-1-naphthalenesulfonic acid fluorescence, and dynamic light scattering. Free amino groups were determined before and after the BITC conjugation. Finally, mass spectrometric analysis of the BITC- $\alpha$-LA protein hydrolysates was performed. As a result of the chemical modifications, a change in the secondary structure of $\alpha$-LA and an increase in surface hydrophobicity and hydrodynamic radii were documented. BITC modification at the $\varepsilon$-amino group of certain lysine side chains inhibited tryptic hydrolysis. Furthermore, two BITC-modified amino acids were identified, located at two lysine side chains (K32 and K113) in the amino acid sequence of $\alpha$-LA.
\end{abstract}

Keywords: rotein modifications; $\alpha$-lactalbumin; whey proteins; benzyl isothiocyanate; cd spectroscopy; hydrophobicity; hydrodynamic radius; tryptic digestion; mass spectrometric analysis

\section{Introduction}

It is well known that a balanced diet is crucial for maintaining good health [1]. With the aim of increasing the consumption of vegetables with their health-promoting secondary plant metabolites, different recipes of traditional foods are improved with higher amounts of vegetables. Especially, vegetables of the plant order Brassicales are associated with multiple health-promoting properties, largely due to the glucosinolates (GLS) or their hydrolysis products, in particular, isothiocyanates (ITC) [2-5]. For example, some studies reported anti-inflammatory, antibacterial, as well as antidiabetogenic effects, and it has even been shown that consumption of vegetables rich in GLS can reduce the risk of developing certain types of cancer [6-16].

Due to their high electrophilicity, ITC can interact with proteins in a diverse bunch of foods. They react with nucleophilic groups such as thiol and amino groups in proteins to form thiocarbamates and thioureas (Figure 1), and thus have a significant influence on various protein properties [5]. 


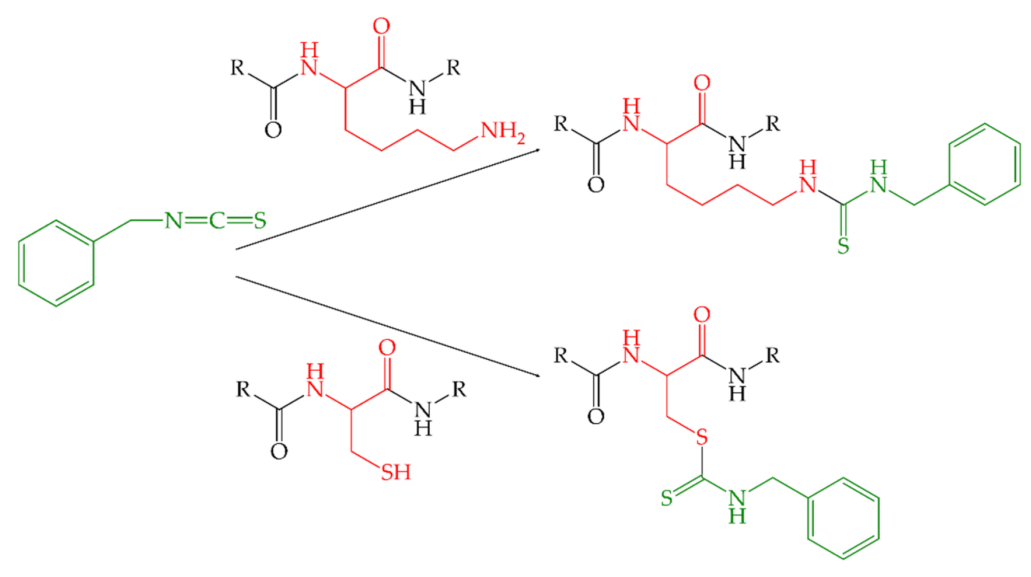

Figure 1. Reaction of benzyl isothiocyanate (BITC) with nucleophilic groups, e.g., of protein side chains. Top: reaction with an amino group to form a thiourea. Bottom: reaction with a thiol group to form a dithiocarbamate, redrawn from [17].

In addition to the formation of reaction products in complex food matrices during food production and processing, interactions between proteins and ITC in the human organism are also conceivable [18-20]. In most cases, such reactions are often considered negatively because they can reduce the bioavailability of the health-promoting secondary metabolites and essential amino acids, as well as affect the physicochemical properties and functionality of proteins [6,9]. However, there might also be a possibility of using the knowledge on the interactions as an opportunity to selectively alter the properties and functionality of proteins $[1,7,9,21-23]$.

Recent research is focusing more and more on the interactions between different food compounds/ingredients. Besides being a good model for studying protein alterations, whey proteins are also very important food proteins. They are of particular interest due to their high content of branched, sulfur-containing, and further essential amino acids. In addition to their outstanding nutritional quality, their functional properties (e.g., gelling, emulsifying, foaming) make them valuable ingredients in different foods/recipes. Furthermore, they have good solubility in a wide $\mathrm{pH}$ range and can serve as carriers for bioactive substances, as their structure is characterized by different domains and hydrophobic pockets [1,24-27]. Next to $\beta$-lactoglobulin ( $\beta$-LG), $\alpha$-lactalbumin $(\alpha-L A)$ is the second most abundant whey protein in cow's milk [24]. $\alpha$-LA is an acidic, monomeric protein with a molecular weight of $14.2 \mathrm{kDa}$, whose amino acids are well characterized, and its sequence is composed of 123 amino acids [28-35]. The structure of $\alpha$-LA is further characterized by four disulfide bonds involving all eight cysteines and a calcium-binding site, which ensures the correct folding and high molecular stability of $\alpha$-LA [24,36-39]. While the secondary structure of native $\alpha$-LA consists of $26 \% \alpha$-helices, $14 \% \beta$-sheets, and $60 \%$ disordered structures [36], the tertiary structure is built up from two domains: a large $\alpha$-domain and a small $\beta$-domain (Figure 2) [37].

Previous studies showed that the interaction of $\beta$-LG with secondary plant metabolites can mask the bitter taste of the latter and contribute to its stabilization and solubility $[40,41]$. In addition, it was found that the covalent modification with ITC affected the physiological and technofunctional properties of proteins. For example, it was documented that the binding of ITC to several proteins resulted in a change in protein conformation [9,42-44]. Further studies proved that the binding of allyl isothiocyanate (AITC, a hydrolysis product of the glucosinolate sinigrin) to $\beta$-LG resulted in a change in the folding and structure of the protein accompanied by an optimization of technofunctional properties such as heat aggregation, foam formation, and emulsification compared to untreated protein [1]. Derivatization of AITC to whey protein isolate also showed an effect on secondary structure depending on $\mathrm{pH}$ value. This was accompanied by changes in physicochemical properties such as aggregation, charge, and hydrophobic regions of the protein surface [9]. In addition, 
it was reported that the binding of the hydrophilic lysine side chains with hydrophobic ligands, such as those represented by the ITC, resulted in a decrease in water solubility and isoelectric point $[45,46]$. Similarly, Rawel et al. (2002), who studied the interaction of ITC with various plant proteins, showed that the derivatives exhibited a decreased solubility and a reduced number of free $\varepsilon$-amino groups, which was accompanied by increased hydrophobicity. In addition, inhibition of tryptic degradation of the ITC derivatives was documented as well [42]. It was reported that, depending on the amount of AITC used, steric blocking of the tryptic cleavage sites of $\beta$-LG was caused, resulting in elongated peptides and affecting the amount of bioactive peptides after proteolytic hydrolysis [7].

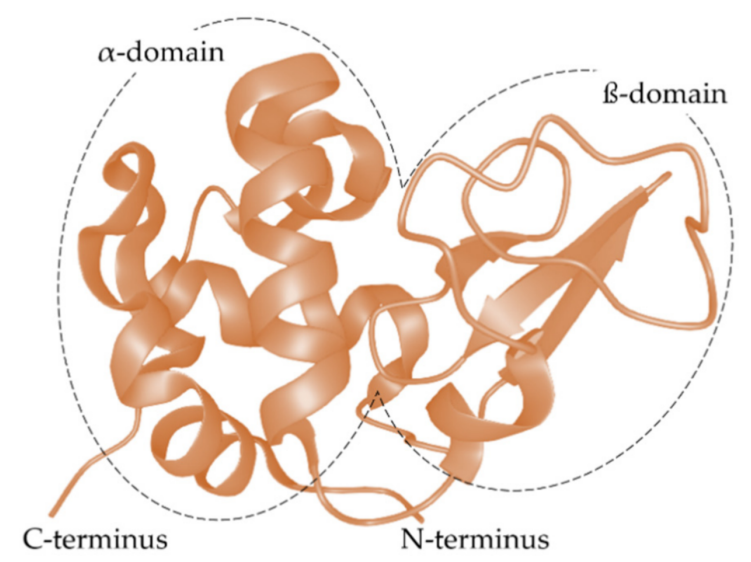

Figure 2. Ribbon model of the conformational structure of bovine $\alpha$-lactalbumin (PDB ID 1F66S), redrawn from [37].

In a recent publication, the allergenic properties of unmodified and BITC-modified $\alpha$-LA and their hydrolysates have already been estimated [47]. A significant influence on the allergenicity of the protein conjugates, but also on the residual antigenicity of the peptides after tryptic digestion, was found. It was hypothesized that as a result of the BITC-addition, there was a change in protein conformation and a corresponding influence on allergenic properties [47]. However, this needs confirmation, as the effects of covalent interactions are complex and can influence protein folding or the three-dimensional structure successively, being crucial for technofunctional and functional properties (e.g., viscosity, gelling, foam formation, solubility, emulsification, color, smell, and taste), as well as biological characteristics such as digestibility [48-50]. Although the reactions of ITC and whey proteins have already been studied several times, it is not yet possible to predict the effect of modification on protein structure and function [1,51]. Further structural characterization of unmodified and ITC-modified proteins remains highly important to estimate the impact on protein structure and functionality and to avoid or even use such covalent modifications to optimize protein functionality in the future.

Based on those findings, the present study aimed at characterizing the influence of the binding benzyl isothiocyanate (BITC), which is a degradation product of the glucosinolate glucotropaeolin to the whey protein $\alpha$-LA as a model. It was hypothesized that BITC-conjugation affects the structure and conformation of $\alpha$-LA and, consequently, its properties and functions. The molecular and supramolecular properties of $\alpha$-LA, as well as digestibility by trypsin upon interaction with BITC, were investigated. For this purpose, an estimation of the secondary structure elements by circular dichroism spectroscopy and an investigation of the surface hydrophobicity using a hydrophobic probe of the BITC- $\alpha$-LA conjugates were performed. Furthermore, the size of the BITC-adducts and the aggregation behavior were studied using dynamic light scattering. Finally, digestibility with the protease trypsin before and after ITC conjugation was analyzed. 


\section{Results}

\subsection{Determination of Free Amino Groups Using O-Phthaldialdehyde}

In the present study, free amino groups in untreated and BITC-modified $\alpha$-LA were determined. The aim was to characterize the effect of BITC conjugation on the amount of residual free amino groups of $\alpha$-LA and to describe the degree of modification based on the change in spectrophotometrical absorbance. Table 1 lists the average contents of the free amino groups along with the standard deviation (SD) as a function of the molar ratios used $\left(\mathrm{B}_{\text {BITC } / \alpha \text {-LA }}\right)$.

Table 1. Free amino group content of the unmodified $\alpha$-LA and BITC- $\alpha$-LA derivatives.

\begin{tabular}{cccc}
\hline Sample & B $_{\text {BITC/ } \alpha \text {-LA }}$ & $\begin{array}{c}\text { Free-NH } \\
\text { Content (\%) }\end{array}$ & SD (\%) \\
\hline$\alpha$-LA control & 0 & 100 & - \\
BITC- $\alpha$-LA derivative "minimal" & 10 & 87.2 & 3.6 \\
BITC- $\alpha$-LA derivative "minor" & 25 & 88.0 & 2.0 \\
BITC- $\alpha$-LA derivative "low" & 50 & 79.3 & 2.1 \\
BITC- $\alpha$-LA derivative "medium" & 500 & 61.8 & 17.5 \\
BITC- $\alpha$-LA derivative "high" & 1000 & 59.9 & 15.4 \\
BITC- $\alpha$-LA derivative "very high" & 1500 & 59.0 & 8.8 \\
\hline
\end{tabular}

The measurement of the $\alpha$-LA control $\left(\mathrm{B}_{\mathrm{BITC} / \alpha \text {-LA }}=0\right)$ represents the maximum amount of free amino groups in the unmodified protein and sets the basis for the evaluation of residual amounts. To facilitate comparison of the spectra, normalization to the free amino group content of the $\alpha$-LA control was performed. Table 1 shows a decrease in the amount of free amino groups from $100 \%$ to $59.0 \%$ with increasing $B_{\mathrm{BITC} / \alpha \text {-LA }}$ from 0 to 1500 . The mean percental amount of free amino groups available in the $\alpha$-LA derivatives with a $\mathrm{B}_{\mathrm{BITC} / \alpha \text {-LA }}$ molar mass ratio of 10 and 25 decreased by approximately $12-13 \%$. While a further reduction in accessible amino groups to $79.3 \pm 2.1 \%$ was noted at a molar mass ratio $\mathrm{B}_{\mathrm{BITC} / \alpha \text {-LA }}$ of 50 , the results indicated saturation when molar mass ratios $\mathrm{B}_{\mathrm{BITC}} / \alpha$-LA were increased further from 500 to 1500 . With increasing molar mass ratios $B_{B I T C / \alpha \text {-LA }}$ from 50 to 1000 or 1500, a further decrease of free amino groups was noted with $61.8 \pm 17.5 \%$, $59.9 \pm 15.4 \%$, and $59.0 \pm 8.8 \%$, respectively.

\subsection{Investigation of Secondary Structure by Far-UV Circular Dichroism Spectroscopy}

For evaluating structural changes of $\alpha$-LA derivatives, circular dichroism (CD) spectroscopy was performed in the far UV range from 185 to $260 \mathrm{~nm}$ to investigate the possible influence of BITC conjugation on the secondary structure of $\alpha$-LA. Spectra of ellipticity as a function of wavelength were recorded for all samples studied. Figure 3 shows averaged normalized CD spectra obtained for the three BITC- $\alpha$-LA derivatives, "low", "medium", and "high"; the untreated control sample; and the $\alpha$-LA in the native state.

The CD spectrum of the native $\alpha$-LA showed a positive maximum at $190 \mathrm{~nm}$ and two negative bands at approximately 208 and $220 \mathrm{~nm}$. The CD spectra of the BITC protein derivatives possess a similar shape with minor changes that became more concise with increasing concentrations of BITC used for treatment. While the values of the molar ellipticity of the positive band at approximately $190 \mathrm{~nm}$ and those of the negative bands at 208 and $220 \mathrm{~nm}$ showed no significant changes between the native, the untreated control sample, and the BITC- $\alpha$-LA derivative "low," a decrease in the positive molar ellipticity at $190 \mathrm{~nm}$ and an increase in the negative molar ellipticity of the minima at 208 and $220 \mathrm{~nm}$ was noted with increasing BITC concentration in the BITC- $\alpha$-LA derivatives "medium" and "high". 


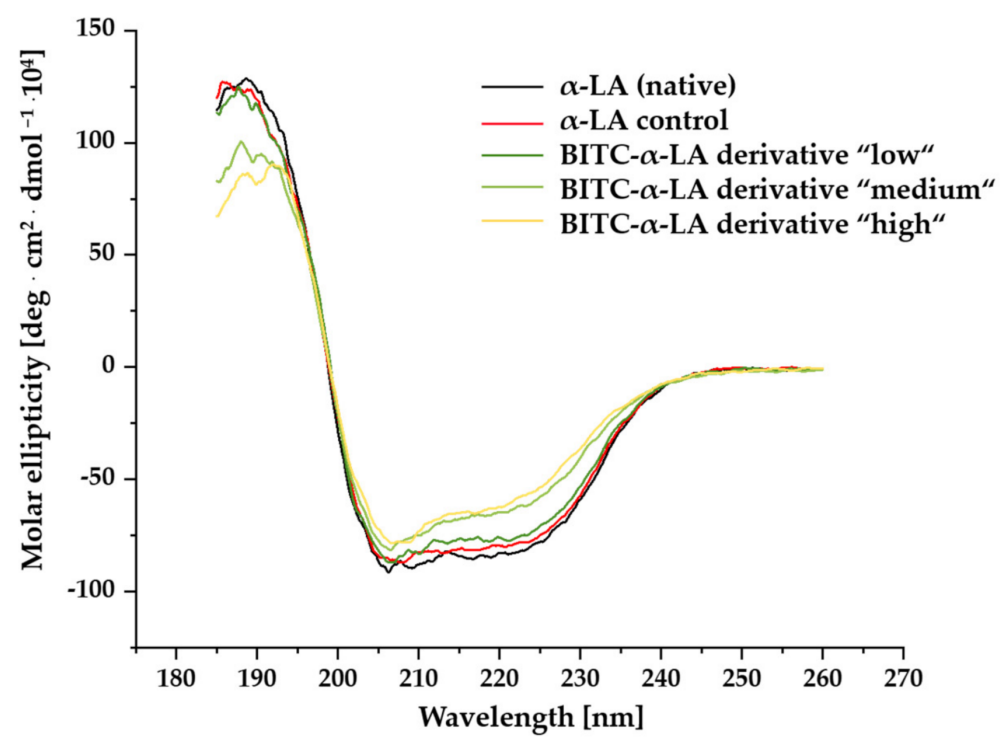

Figure 3. Far-UV CD spectrum of $\alpha$-LA in the absence and presence of BITC.

To gain a better understanding of the structural effects of BITC conjugation, the $\mathrm{CD}$ spectra of all samples were subjected to quantitative measurement to evaluate the secondary structure and/or to estimate the changes caused in the secondary structure. Quantitative determination of the percentages of secondary structures of three BITC- $\alpha$-LA derivatives "low", "medium" and "high"; the untreated control sample; and the native $\alpha$-LA was performed using the K2d method in DichroWeb (http:/ / dichroweb.cryst.bbk.ac. $\mathrm{uk} / \mathrm{html} /$ links.shtml; accessed on 10 October 2021) and is summarized in Table 2.

Table 2. Quantification of the secondary structural composition of the proteins at $20{ }^{\circ} \mathrm{C}$ and $80{ }^{\circ} \mathrm{C}$.

\begin{tabular}{ccccc}
\hline Sample & $\begin{array}{c}\text { Temperature } \\
\left({ }^{\circ} \mathbf{C}\right)\end{array}$ & $\boldsymbol{\alpha}$-Helix (\%) & $\beta$-Sheet (\%) & $\begin{array}{c}\text { Random Coil } \\
\mathbf{( \% )}\end{array}$ \\
\hline LA (native) & 20 & 30 & 12 & 58 \\
\hline \multirow{2}{*}{$\alpha$-LA control } & 20 & 29 & 13 & 58 \\
\hline BITC- $\alpha$-LA-derivative & 80 & 15 & 15 & 70 \\
"low" & 20 & 24 & 19 & 57 \\
\hline BITC- $\alpha$-LA-derivative & 80 & 19 & 12 & 69 \\
"medium" & 20 & 20 & 25 & 56 \\
\hline BITC- $\alpha$-LA-derivative & 80 & 18 & 19 & 63 \\
"high" & 20 & 17 & 28 & 55 \\
\hline
\end{tabular}

The results showed that native $\alpha$-LA consisted of approximately 30\% $\alpha$-helix, $12 \%$ $\beta$-sheet, and $58 \%$ regions of low structural complexity. Binding of BITC induced variations in the content of $\alpha$-helix and $\beta$-sheet structures. With increasing BITC concentration, the amount of $\alpha$-helix successively decreased from $29 \%$ to $17 \%$ and, at the same time, the amount of $\beta$-sheet structures increased from $12 \%$ to $28 \%$. No significant change due to BITC conjugation was observed for the regions with lower structural complexity.

\subsection{Investigation of Temperature-Induced Conformational Changes Using Far-UV CD Spectroscopy}

In the following, under the aspect of evaluating the temperature-induced conformational changes of BITC- $\alpha$-LA derivatives, far-UV CD spectroscopy was performed at different temperatures. Knowledge about the temperature-dependent folding stability of $\alpha$-LA is of great interest in food technology, as it significantly influences the functional and nutritional properties of foods (e.g., dairy products in the case of $\alpha$-LA). For this purpose, 
$\mathrm{CD}$ spectra of the untreated and BITC-treated $\alpha$-LA were recorded in a temperature range from 30 to $80^{\circ} \mathrm{C}$ with a heating interval of $2{ }^{\circ} \mathrm{C} / \mathrm{min}$. Figure 4 shows the $\mathrm{CD}$ spectra of the unmodified $\alpha$-LA control (a) and the BITC- $\alpha$-LA derivatives "low" (b), "medium" (c), and "high" (d).
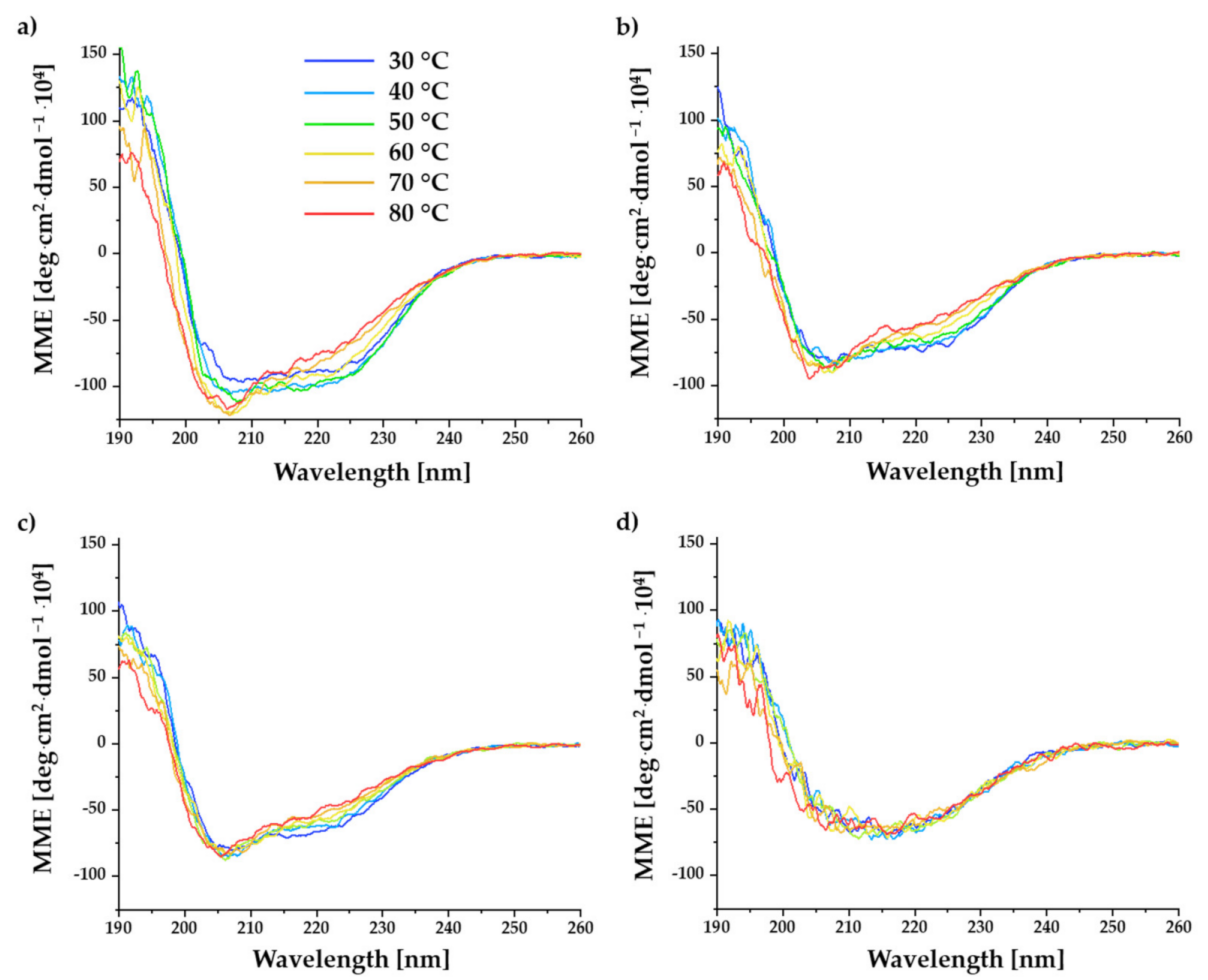

Figure 4. $\mathrm{CD}$ spectra of the BITC- $\alpha$-LA derivatives recorded at different temperatures ranging from 30 to $80^{\circ} \mathrm{C}$. Control sample (a), BITC- $\alpha$-LA derivative "low" (b), BITC- $\alpha$-LA derivative "medium" (c), and BITC- $\alpha$-LA derivative "high" (d).

The CD spectrum obtained for the $\alpha$-LA control (Figure 4a) showed a decrease in the molar ellipticities of the double minimum and an increase in the molar ellipticities of the maximum at $190 \mathrm{~nm}$ in the temperature range from 30 to $50^{\circ} \mathrm{C}$. While the molar ellipticity of the minimum at $208 \mathrm{~nm}$ continued to decrease with increasing temperature $\left(60-80{ }^{\circ} \mathrm{C}\right)$, the molar ellipticity of the minimum at $222 \mathrm{~nm}$ increased. In parallel, a decrease of the maximum at $190 \mathrm{~nm}$ was observed in the temperature course from 60 to $80^{\circ} \mathrm{C}$.

In the CD spectra of the BITC- $\alpha$-LA derivatives "low" and "medium" (Figure $4 b, c)$, a steady decrease in the molar ellipticity of the maximum and an increasing molar ellipticity of the minimum at $222 \mathrm{~nm}$ could already be observed for temperatures $\geq 40{ }^{\circ} \mathrm{C}$. A significant difference between these two derivatives was that with increasing temperature (from about $60^{\circ} \mathrm{C}$, analogous to the control) in the derivative "low", the minimum at $208 \mathrm{~nm}$ showed a slight decrease in molar ellipticity, while in the derivative "medium" no significant change was observed. It should be emphasized that the differences with increasing temperature were only slightly lower for the BITC- $\alpha$-LA derivative "medium", while no significant changes were documented for the BITC- $\alpha$-LA derivative "high" when evaluated as a function of temperature. In summary, the differences in the CD spectra as a function of temperature became increasingly smaller with an increasing degree of derivatization/modification. Furthermore, the observations described can be supported by comparing the approximated secondary structure compositions for the different derivatives at the different temperatures applied (Table $2 ; 20^{\circ} \mathrm{C}$ and $80^{\circ} \mathrm{C}$ ), corresponding to the $\mathrm{CD}$ spectra shown in Figure 4. 


\subsection{Investigation of Surface Hydrophobicity Using Anilino-1-Naphthalenesulfonic} Acid (ANS) Fluorescence

In the following, the effect of BITC conjugation on the surface hydrophobicity of $\alpha$-LA was investigated using the extrinsic fluorescent dye anilino-1-naphthalenesulfonic acid (ANS). It can be used to evaluate conformational changes in proteins and to characterize hydrophobic binding sites on the surface of proteins $[1,52-60]$. In Figure 5, the mean ANS fluorescence intensities of the untreated $\alpha$-LA control sample and BITC- $\alpha$-LA derivatives "low", "medium", "high", and "very high" are plotted against wavelength.

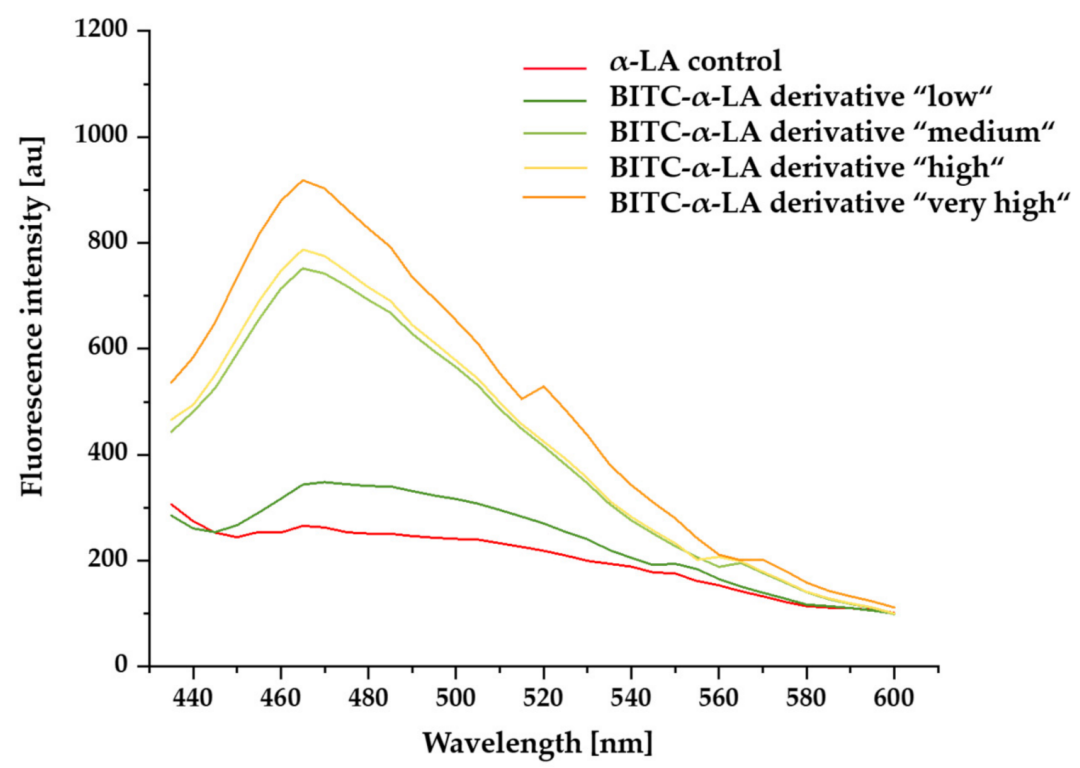

Figure 5. Mean fluorescence intensities versus wavelength of the ANS assay of the BITC- $\alpha$-LA derivatives.

Low fluorescence emission was observed in the presence of unmodified $\alpha$-LA (Figure 5, red curve). Depending on the degree of BITC modification, a difference in fluorescence intensity between the measured samples was documented. While the control sample showed a low fluorescence intensity compared to the BITC-treated protein derivatives, a significant increase in ANS fluorescence and a shift of the fluorescence maximum was observed with an increasing degree of modification. Measurement of the ANS fluorescence of the BITC- $\alpha$-LA derivative "low" showed only a slight increase in intensity and hardly any effect on the position of the fluorescence maximum (Figure 5, dark green curve). With an increasing degree of modification of the $\alpha$-LA derivatives, the ANS quantum yield could be increased up to a threefold value, and a blue shift of the fluorescence maximum was observed.

\subsection{Determination of the Hydrodynamic Radius Using Dynamic Light Scattering}

Using dynamic light scattering, the hydrodynamic radius and aggregation behavior of the untreated protein and BITC- $\alpha$-LA- derivatives were evaluated. Figure 6 shows the size distribution histograms of the untreated $\alpha$-LA protein control and the BITC- $\alpha$-LA derivatives "low", "medium", "high", and "very high". For each sample, 20 scans were acquired, resulting in the average hydrodynamic radius and the correspondingly standard deviation (Table 3). 


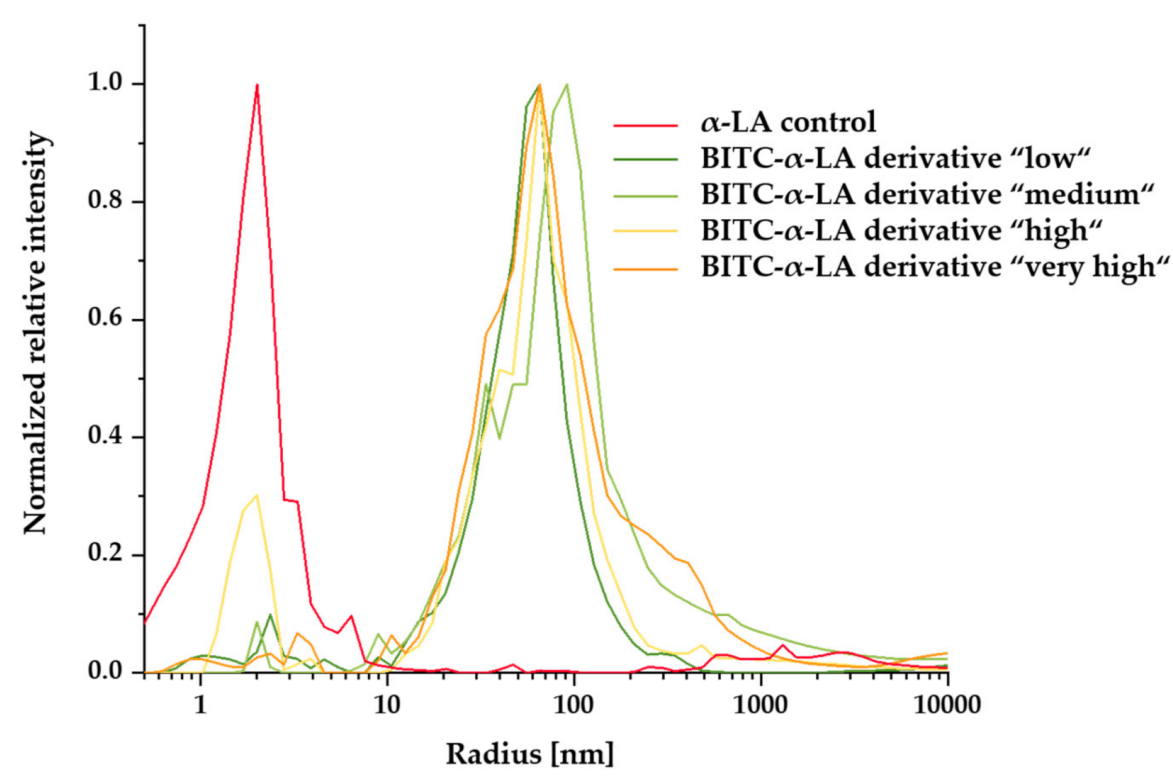

Figure 6. Distribution of hydrodynamic radii of the $\alpha$-LA control and the BITC- $\alpha$-LA derivatives.

Table 3. Averaged hydrodynamic radii $\left(R_{H}\right)$ along with standard deviations (SD) of $\alpha$-LA control and BITC- $\alpha$-LA derivatives ( $n=20$ scans).

\begin{tabular}{|c|c|c|c|c|}
\hline Sample & No. & $\begin{array}{l}\mathbf{R}_{\mathbf{H}}( \pm \mathrm{SD}) \\
\quad(\mathbf{n m})\end{array}$ & No. & $\begin{array}{c}\mathbf{R}_{\mathbf{H}}( \pm \mathbf{S D}) \\
\quad(\mathbf{n m})\end{array}$ \\
\hline$\alpha$-LA control & I & $1.8( \pm 0.2)$ & & \\
\hline $\begin{array}{c}\text { BITC- } \alpha \text {-LA-derivative } \\
\text { "low" }\end{array}$ & $\begin{array}{l}\text { I } \\
\text { III } \\
\text { V }\end{array}$ & $\begin{array}{c}2.4( \pm 0.5) \\
13.8( \pm 3.2) \\
57.8( \pm 11.5)\end{array}$ & $\begin{array}{l}\text { II } \\
\text { IV }\end{array}$ & $\begin{array}{c}2.9( \pm 0.7) \\
15.8( \pm 3.5)\end{array}$ \\
\hline $\begin{array}{l}\text { BITC- } \alpha \text {-LA-derivative } \\
\text { "medium" }\end{array}$ & I & $83.8( \pm 18.3)$ & II & $89.4( \pm 14.9)$ \\
\hline $\begin{array}{l}\text { BITC- } \alpha \text {-LA-derivative } \\
\text { "high" }\end{array}$ & $\begin{array}{c}\text { I } \\
\text { III }\end{array}$ & $\begin{array}{c}2.0( \pm 0.3) \\
61.0( \pm 13.6)\end{array}$ & II & $55.5( \pm 11.3)$ \\
\hline $\begin{array}{l}\text { BITC- } \alpha \text {-LA-derivative } \\
\text { "very high" }\end{array}$ & $\begin{array}{c}\text { I } \\
\text { III }\end{array}$ & $\begin{array}{l}51.6( \pm 11.7) \\
68.6( \pm 15.6)\end{array}$ & II & $62.1( \pm 11.8)$ \\
\hline
\end{tabular}

For the untreated $\alpha$-LA control, the hydrodynamic radius was $1.8 \pm 0.2 \mathrm{~nm}$, indicative of monomeric $\alpha$-LA. Moreover, only a single signal with a small peak width was observed in the histogram of the unmodified $\alpha$-LA control, leading to the assumption that the solution was monodisperse and homogeneous. In contrast, multiple particle sizes and broader peaks were observed for the BITC- $\alpha$-LA derivatives. Depending on the degree of modification, increased hydrodynamic radii from 13.8 to $89.4 \mathrm{~nm}$ were observed, indicating a polydisperse and inhomogeneous solution of large multimers.

\subsection{LC-ESI-MS/MS Analysis of Unmodified and BITC-Modified $\alpha$-LA Hydrolysates}

One aim of these approaches was to identify the side chains of the $\alpha$-LA protein modified with BITC and to investigate the influence on the digestibility of the protein derivatives. For this purpose, the four different BITC- $\alpha$-LA derivatives, "low", "medium", "high" and "very high", with different BITC concentrations and the unmodified $\alpha$-LA control sample were subjected to tryptic digestion. The protein hydrolysates were then analyzed by LC-MS/MS. The comparison of the total ion chromatogram of the $\alpha$-LA control and the BITC- $\alpha$-LA derivatives "low" and "very high" is shown exemplarily in Figure 7. 
Table 4. Summary of all identified peptides after tryptic hydrolysis of the unmodified control sample (K) and BITC- $\alpha$-LA derivatives. The numbering, the corresponding peptide mass, and the associated retention time are listed. Peptides that have been modified are marked with an "*", while elongated peptides resulting from BITC modification were highlighted with "***".

\begin{tabular}{|c|c|c|c|c|c|c|c|}
\hline No. & Peptide Sequence & Mass $(m / z)$ & Control & Low & Medium & High & $\begin{array}{l}\text { Very } \\
\text { High }\end{array}$ \\
\hline 1 & EQLTK & 618.35 & 10.7 & 10.9 & 11.2 & 11 & 11.2 \\
\hline 1 * & EQLTK + BITC & 767.56 & - & 29.7 & 29.8 & 30.5 & 30.3 \\
\hline 2 & CEVFR & 653.31 & 19.1 & - & - & - & - \\
\hline 3 & ELK & 389.24 & 4.5 & 4.5 & 4.6 & 4.5 & 4.6 \\
\hline $3 *$ & ELK + BITC & 538.45 & - & - & - & - & 29.3 \\
\hline $3 * *$ & ELKDLK + BITC & 894.17 & - & - & 27.0 & 26.9 & 26.8 \\
\hline 4 & DLK & 375.22 & 5.2 & 5.3 & 5.3 & 5.2 & 5.2 \\
\hline 5 & $\begin{array}{c}\text { GYGGVSLPEWVCTTFHTSGYD- } \\
\text { TQAIVQNNDST- } \\
\text { EYGLFQINNK }\end{array}$ & 4654.15 & - & - & - & - & - \\
\hline 6 & IWCK & 549.29 & 18 & - & - & - & - \\
\hline 7 & DDQNPHSSNICNISCDK & 1889.78 & 16.6 & 17.0 & 16.8 & 17 & 18.1 \\
\hline 8 & FLDDDLTDDIMCVK & 1642.73 & - & - & - & - & - \\
\hline 9 & $\mathrm{~K}$ & 147.11 & - & - & - & - & - \\
\hline $9 * *$ & KILDK + BITC & 765.61 & - & 23.4 & 23.3 & 23.2 & 23.3 \\
\hline 10 & ILDK & 488.31 & 16.1 & 16.1 & 16.1 & 16.1 & 16.0 \\
\hline $10 *$ & ILDK + BITC & 637.52 & - & - & - & 32.5 & 32.7 \\
\hline 11 & VGINYWLAHK & 1220.65 & 20.9 & 20.9 & 20.3 & 21.3 & 20.7 \\
\hline 12 & ALCSEK & 650.32 & 16.4 & 15.9 & 15.8 & 15.7 & 16.2 \\
\hline $12 * *$ & ALCSEKLDQWLCEK + BITC & 1815.1 & - & - & - & - & 31.8 \\
\hline 13 & LDQWLCEK & 1034.50 & 20 & 21.2 & 23.5 & 24.5 & 23.2 \\
\hline 13 * & LDQWLCEK + BITC & 1183.71 & - & 34.1 & 33.8 & 34.4 & 33.4 \\
\hline 14 & $\mathrm{~L}$ & 132.10 & - & - & - & - & - \\
\hline
\end{tabular}

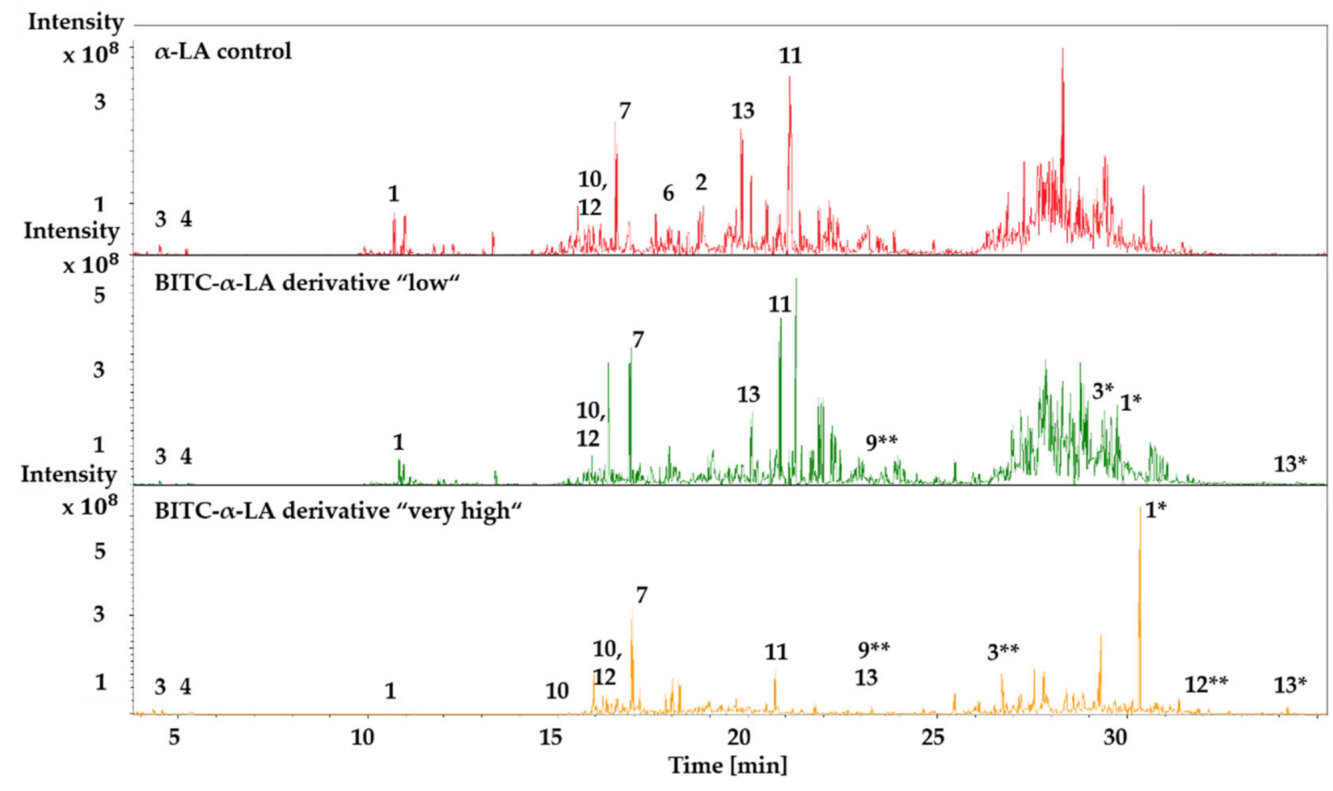

Figure 7. Total ion chromatograms (TIC) of the tryptically hydrolyzed untreated $\alpha$-LA (red) and the tryptically hydrolyzed BITC- $\alpha$-LA derivatives "low" (green) and "very high" (orange). The main peptide signals were labeled numerically. Identical peptide sequences are marked with the same number, corresponding peptides that have been modified are marked with an "*", while elongated peptides resulting from BITC modification were highlighted with "***". The numbering of the peptides is given in Table 4. 
Upon reaction of $\alpha$-LA with BITC and subsequent hydrolysis to peptides, new signals representing BITC-modified peptides were observed. A corresponding decrease in signal intensity of the unmodified peptides was noted as well. Overall, it was found that a mixture of modified and unmodified peptides was the result for the BITC derivatives. The elution of the protein hydrolysates took place between 5 and $35 \mathrm{~min}$.

The PeptideMass tool at www.expasy.org (accessed on 20 September 2021) was used to run an in silico tryptic hydrolysis of the $\alpha$-LA protein. Here, the theoretically generated peptides, as well as their mass and positions in the protein sequence, were provided. The protein sequence of $\alpha$-LA was taken from the UniProtKB database (http:/ / www.uniprot. org /; accessed on 20 September 2021); under UniProt entry name LALBA_BOVIN and file number P00711). Theoretically, tryptic hydrolysis of native, unmodified $\alpha$-LA generates 14 peptides. Table 4 lists all identified amino acid sequences of the control sample as well as the derivatives.

Of the 14 theoretical peptides, 10 could be detected in the $\alpha$-LA control, whereas 8 unmodified peptides could still be identified in all BITC- $\alpha$-LA derivatives. The peptide sequences IWCK and CEVFR could only be observed for the control. In addition to the eight unmodified peptides of the derivatives, several modified peptides were detected. A total of 11 peptides were identified for the BITC- $\alpha$-LA derivative "low", 12 peptides for the BITC- $\alpha$-LA derivative "medium," 13 peptides for the BITC- $\alpha$-LA derivative "high," and 15 peptides for the BITC- $\alpha$-LA derivative "very high". Compared to the native protein, a higher number of peptides were identified after BITC conjugation because of the total sum of unmodified and modified peptides. Furthermore, a concentration-dependent modification of the peptides was observed (Table 4). While the modified $\mathrm{N}$-terminal and C-terminal sequences EQLTK and LDQWLCEK, respectively, were identified in all derivatives, other peptides were only derivatized at higher BITC concentrations. For example, the modification of the peptide sequence ILDK could only be identified in the derivatives "high" and "very high" and the sequence ELK only in the derivative "very high". With an increasing degree of modification, longer peptide sequences were detected. These peptides were ELKDLK (No. $3^{* *}$ ), KILDK (No. 9**), and ALCSEKLDQWLCEK (No. 12**). BITC-modified ELKDLK was detected in the derivatives "medium", "high", and "very high", whereas BITC-modified KILDK was identified only in the derivatives "high" and "very high". The modified peptide sequence ALCSEKLDQWLCEK was only observed in the derivative "very high". Furthermore, as obvious from Figure 6 and Table 4, BITC-modified peptides were eluted at later retention times. For example, the unmodified peptide EQLTK was eluted at 10-11 $\mathrm{min}$ in the $\alpha$-LA control and derivatives, whereas the corresponding modified peptide was eluted at $30 \mathrm{~min}$. Similar effects have been observed for the peptides ELK, ILDK, and LDQLCEK.

\section{Identification of BITC-Modified Amino Acids}

In mass spectrometry, information about the amino acid sequence of peptides/proteins can be obtained using different fragmentation methods [61]. On the one hand, it is possible to reconstruct the amino acid sequence of peptides and identify proteins from the fragmentation patterns. On the other hand, post-translational modifications such as BITC modification can be identified and localized as well. Depending on the fragmentation method chosen, different breaking points in the backbone of the peptides can be observed. For example, fragmentation yields $a$ - and $x$-ions before peptide binding, $b$ - and $y$-ions in peptide binding, and $c$ - and $z$-ions following peptide binding. While the fragments of the $C$-terminal series are defined as $x-, y-$, and $z$-ions, the fragments of the $N$-terminal series are designated as a, b, and c (Figure 8). The labile amide bond in peptides is particularly susceptible to fragmentation, resulting in a breakage of the backbone between individual amino acids and resulting in $N$-terminal $b$-ion series and $C$-terminal $y$-ion series. Peptide bond fragmentation produces a ladder-like representation of the amino acid sequence in the MS/MS spectrum [62,63]. 


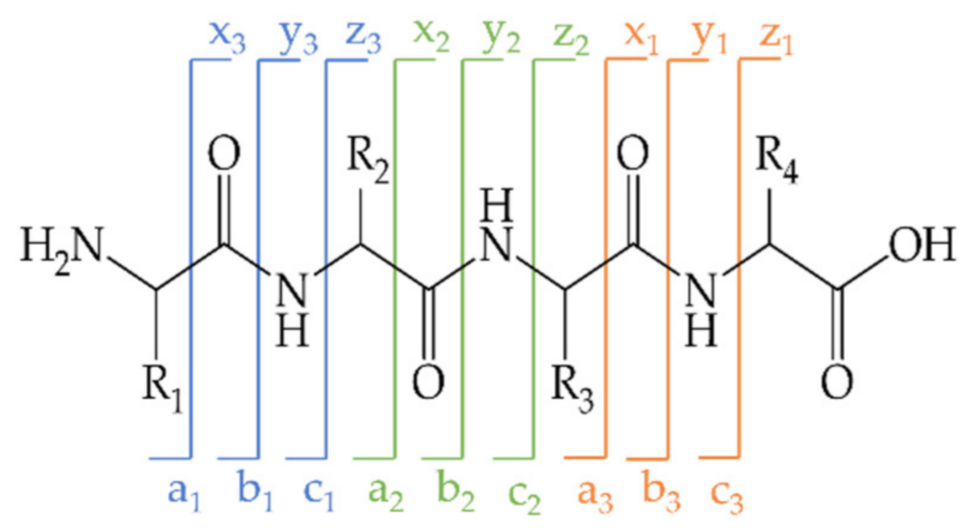

Figure 8. Designation of $N$ - and $C$-terminal peptide fragments; redrawn from $[62,63]$.

In the present study, a modified amino acid could be identified in the peptide sequences ELKDLK and KILK. As an example, the results are presented using the MS/MS spectra of the derivative "very high". To identify the modified amino acid, the $y$-and $b$-fragment ions for the corresponding peptides were first calculated using the proteomic tool of the Institute for Systems Biology, Seattle, WA, USA (http:/ / db.systemsbiology.net: 8080 / proteomicsToolkit/FragIonServlet.html; accessed on 20 September 2021). As posttranslational modifications with BITC $(\mathrm{M}=149.21 \mathrm{~g} / \mathrm{mol})$ change the mass of an amino acid or peptide, the masses for all $y$ - and $b$-ions were calculated in the case of modification at the corresponding amino acid (marked with *). Tables 5 and 6 show the numbering of the $y$ - and $b$-fragment ions and their masses in the native or BITC-modified state (marked with *) for the sequences ELKDLK and KILDK; the identified $y$ - and $b$-fragment ions of the modified peptides were illustrated in bold font. Figure $9 a, b$ show the MS/MS spectra of the double- and single-charged ions with an $\mathrm{m} / z$ of 447.72 and an $m / z$ of 894.46 , which can be assigned to the modified peptide ELKDLK. Figure $9 \mathrm{c}$ shows the MS/MS spectrum of the modified peptide KILDK with an $m / z$ of 765.38 . The identified $y$ - and $b$-fragment ions of the modified peptides were highlighted in orange and green in Figure 9 according to the nomenclature from the Tables 5 and 6 .

Table 5. Mass of unmodified and modified $y$ - and $b$-fragment ions of the sequence ELKDLK.

\begin{tabular}{ccccccc}
\hline Sequence & No. & $\boldsymbol{b}$-Ions & $\boldsymbol{b}^{*}$-Ions & $\boldsymbol{y}$-Ions & $\boldsymbol{y}^{*}$-Ions & No. \\
\hline E & 1 & 130.05 & 279.26 & 745.45 & 894.66 & 6 \\
L & 2 & 243.13 & 392.34 & 616.40 & 765.61 & 5 \\
K & 3 & 371.23 & 520.44 & 503.32 & 652.53 & 4 \\
D & 4 & 486.26 & 635.47 & 375.22 & 524.43 & 3 \\
L & 5 & 599.34 & 748.55 & 260.20 & 409.41 & 2 \\
K & 6 & 727.43 & 876.64 & 247.11 & 296.32 & 1 \\
\hline
\end{tabular}

Table 6. Mass of unmodified and modified $y$ - and $b$-fragment ions of the sequence KILDK.

\begin{tabular}{ccccccc}
\hline Sequence & No. & $\boldsymbol{b}$-Ions & $\boldsymbol{b}^{*}$-Ions & $\boldsymbol{y}$-Ions & $\boldsymbol{y}^{*}$-Ions & No. \\
\hline K & 1 & 129.10 & 278.31 & 616.40 & 765.61 & 5 \\
I & 2 & 242.19 & 391.40 & 488.31 & 637.52 & 4 \\
L & 3 & 355.27 & 504.48 & 375.22 & 524.43 & 3 \\
D & 4 & 470.30 & 619.51 & 262.14 & 411.35 & 2 \\
K & 5 & 598.39 & 747.60 & 147.11 & 296.32 & 1 \\
\hline
\end{tabular}



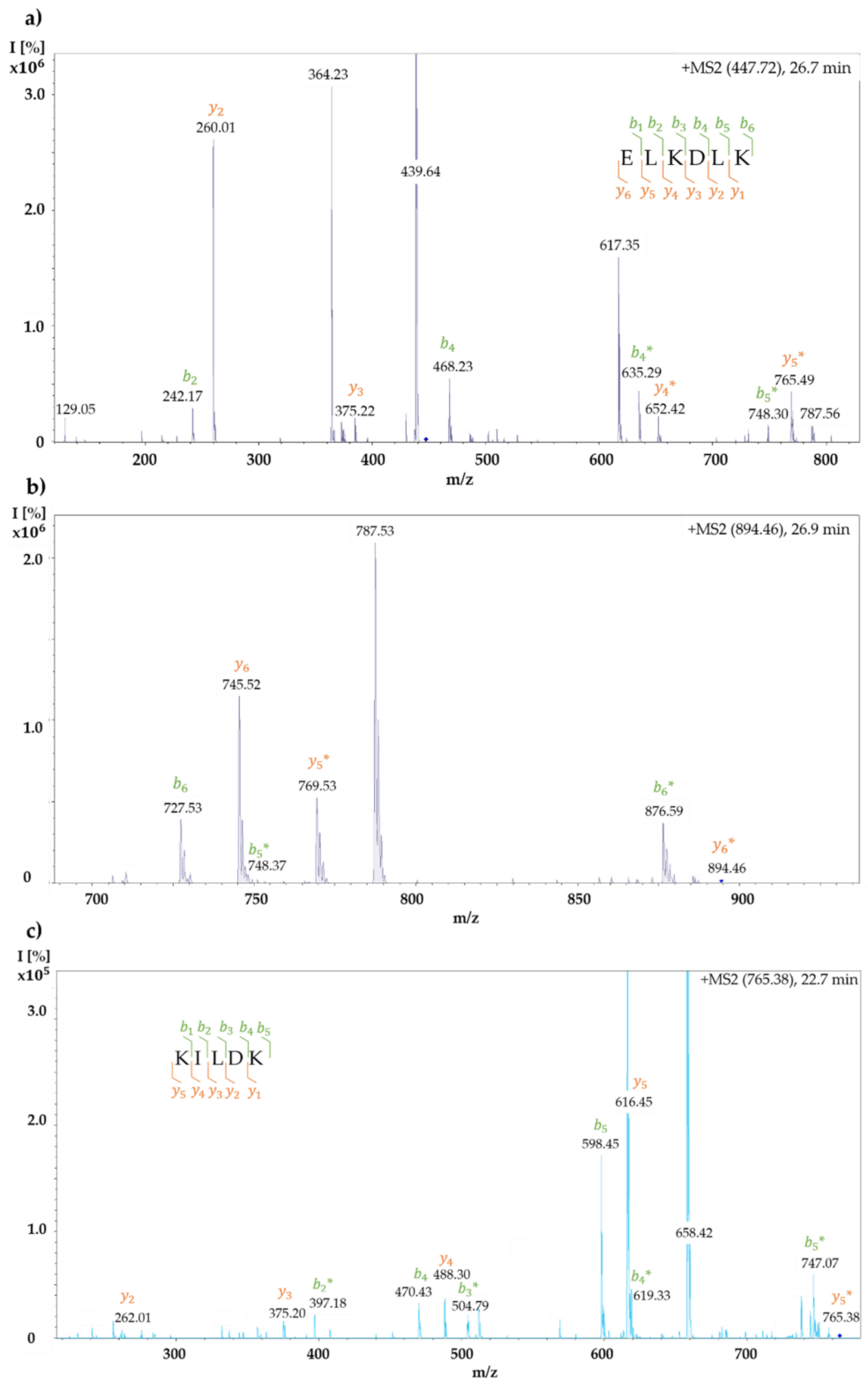

Figure 9. MS/MS spectra of the singly modified peptides ELKDLK of $[\mathrm{M}+2 \mathrm{H}]^{2+}$ with $m / z 447.72$ (a) and of $[\mathrm{M}+\mathrm{H}]^{+}$with $m / z 894.46$ (b) and KILDK of $[\mathrm{M}+\mathrm{H}]^{+}$with $m / z 765.38$ (c). The $b$-fragment ions are shown in green and the $y$-fragment ions are shown in orange.

The signals in the mass spectrum of the modified peptide ELKDLK could be assigned to the theoretically calculated $y$ - and $b$-ions. A nearly complete $y$ - and $b$-ion series was observed, enabling the amino acid sequence of peptide ELKDLK to be identified at a retention time between 26.7 and 26.9 min (Figure 9a,b, Table 5). Similary, the $y$ - and $b$-fragment ions identified the modified peptide KILDK at a retention time of $22.7 \mathrm{~min}$ (Figure 9c, Table 6).

The chemical modification with BITC resulted in a change in the mass of the amino acid or peptide. Thus, the modified amino acid could be identified by corresponding deviating masses of the $y$ - and $b$-fragment ions. In the mass spectrum of the modified peptide ELKDLK, the $b 6-, b 5-$, and $b 4-$ as well as the $y 6-, y 5-$, and $y 4$-fragment ions could be detected with the additional mass of BITC. The $b 3$ - and $b 2$, as well as the $y 3$ and $y 2$ fragment ions, had the mass of the unmodified state, leading to the conclusion that the modification with BITC was present at the central lysine in the amino acid sequence of ELKDLK (Figure 9a,b, Table 5). The mass differences of the $y$ - and $b$-fragment ions of the 
modified peptide KILDK indicated that the BITC-modification occurred at the first lysine of the peptide sequence (Figure 9c, Table 6). However, for the remaining modified peptides, whose masses and sequence could be identified, no clear identification of the modified amino acid was possible due to insufficient detection of the modified $y$ - and $b$-fragment ions. Peptides that have been modified are marked with an "**".

\section{Discussion}

\subsection{Determination of Free Amino Groups Using O-Phthaldialdehyde}

Due to the electrophilic carbon atom of an ITC, a reaction with nucleophiles, such as hydroxy, amino, and thiol groups of protein side chains, is conceivable. While the reactions with thiol groups yield reversible reaction products (dithiocarbamates), the products from the reaction with amino groups are irreversible (thioureas) [17]. Therefore, it was assumed that with increasing BITC concentration (increasing molar ratio $B_{\text {BITC/ } \alpha \text {-LA }}$ ), an increasing degree of modification of the freely accessible amino groups was achieved, making them unavailable for the reaction with ortho-phthaldialdehyde (OPA) and thus, leading to a decrease in absorption.

A total of 13 potential reaction sites for BITC in $\alpha$-LA were assumed, comprising $12 \varepsilon$-amino groups of the amino acid lysine $(\mathrm{K})$ and the $\alpha$-amino group of the $N$-terminal amino acid glutamic acid (E).

The results showed a decreasing trend in the relative mean contents of free amino groups from $100 \%$ to $59.0 \%$ with increasing concentration of BITC for the derivatization of protein conjugates, indicating the formation of thiourea derivatives and an increasing degree of modification of the protein [1,64,65]. Rade-Kukic et al. (2011) already reported a concentration-dependent reaction between AITC and the whey protein $\beta$-LG, observing a decrease in free amino groups with an increasing concentration of AITC present [1]. Similarly, reactions of proteins such as ovomucoid, conalbumin, ovalbumin, myoglobin, insulin, bovine soap albumin, and lysozyme with ITC showed a decrease in the percentage of mean free amino group contents as a function of the amount of ITC used, which was attributed to the formation of thiourea derivatives [43,45,46,66-68]. However, a major difference was that those studies used trinitrobenzenesulfonic acid (TNBS) to determine the free amino groups in ITC-protein conjugates. In that alternative method, proteins react with TNBS to form a trinitrobenzene derivative that can be determined photometrically at $416 \mathrm{~nm}$ [69]. As some studies concluded that the methods were comparable [70], these results were used for comparison.

Furthermore, a previous study showed that the reaction between AITC and mustard with ITC/protein ratios between 25 and 200 was accompanied by a concentrationdependent decrease in the number of free amino groups from $100 \%$ to a maximum of $70 \%$. They described that above an AITC/protein ratio of 100, a constant amount of free amino groups was observed [71]. This result supports the assumption of the present study that there is a stagnant decrease of the free amino groups above a molar mass ratio of 500 .

Moreover, a correlation between the decrease in free amino groups and the solubility of ITC-modified bovine sarcoplasma proteins as a function of the ITC concentration used has been reported in the literature [69]. Rawel et al. (1998) showed that the interactions of ITC with various plant proteins affected the physicochemical properties of the proteins by increasing the derivatization of the proteins with ITC. Both solubility and the amount of free $\varepsilon$-amino groups decreased while hydrophobicity increased [42]. Further studies confirmed the correlation between the decrease in free amino groups and the solubility of the derivatives as a function of the amount of ITC used [45,69]. Additionally, the decrease in hydrophobicity of myoglobin as a result of ITC conjugation was confirmed using a hydrophobic fluorescent probe and RP-HPLC [67].

\subsection{Influence of BITC Conjugation on Secondary Structure of $\alpha-L A$}

Far-UV CD spectroscopy was performed to investigate the effect of BITC conjugation to $\alpha$-LA on the secondary structure of the protein. Circular dichroism (CD) is the 
differential absorption of left and right circularly polarized light by optically active (chiral) molecules. Using $\mathrm{CD}$ spectroscopy, the wavelength-dependent absorption difference $\Delta \mathrm{A}$ of left- and right-circularly polarized light is measured, which is defined as dichroism. It is an analytical method that takes advantage of the optical activity of chiral molecules to elucidate the structure of molecules [48,72-74]. The reason for the different absorption is that chiral molecules have different refractive indices for right- and left-circularly polarized light [72,74]. In the CD measurements, equal but alternating amounts of left- and rightcircularly polarized light of one wavelength pass through an optically active medium. Each light absorption causes a change in the light intensity and consequently in the amplitude of the incident wave. When a chiral substance absorbs left- and right-circularly polarized light to different extents, different amplitudes of the circularly polarized waves result, and the superimposed light is no longer linear but elliptically polarized light $[48,72,73,75]$.

In addition to chiral carbon atoms, optically active chromophores in asymmetric molecular structures such as $\alpha$-helix, $\beta$-sheet can also possess optical activity. Therefore, $\mathrm{CD}$ spectroscopy is widely used to analyze the structures of biomolecules such as proteins and DNA $[75,76]$. In proteins, the peptide bonds are the absorbing group. Their ellipticity changes depending on their conformation. In CD spectroscopy of proteins, the spectra in the ultraviolet region can be divided into near and far UV regions. While CD signals in the short-wave UV region of 170-260 $\mathrm{nm}$ (far UV region) are due to peptide binding, aromatic amino acids and disulfide bridges absorb in the long-wave UV region (near UV region) of 250-300 nm [48,72,73]. Thus, near-UV CD spectroscopy can provide information about the tertiary structure of proteins, while far-UV CD spectroscopy allows conclusions about the secondary structure of proteins or is suitable for characterizing the secondary structure of proteins [49,77-84].

Far UV CD spectroscopy was performed to evaluate the impact of conjugation of BITC on the conformational changes in the secondary structure of $\alpha$-LA. The CD spectra of all samples in Figure 3 showed positive maxima at $190 \mathrm{~nm}$ and negative bands at approximately 208 and $220 \mathrm{~nm}$. The CD bands in Figure 3 were attributed to electronic transitions of a peptide bond in the far UV region [75]. In this spectral region, the amides within the secondary structure components of a protein strongly absorb circularly polarized light and exhibit different numbers of electronic transitions for a given wavelength. Therefore, the CD spectrum of proteins in the far UV region is dominated by the absorption of the peptide bonds, and the absorption is dependent on the orientation and environment of the amide bond [85]. The peptide bond absorption is due to two electronic transitions: a strongly pronounced CD band of the $\pi \rightarrow \pi^{*}$ transition at $190 \mathrm{~nm}$ and a broader but weaker CD band of the des $\eta \rightarrow \pi^{*}$ transition between 210 and $220 \mathrm{~nm}$ (Figure 10A) [48,72,73,75,76,85-87]. In Figure 10B, the characteristic CD spectra of three secondary structures are shown for comparison with the experimentally obtained $C D$ spectra (Figure 3). The CD spectrum of a "pure" $\alpha$-helical structure shows two negative bands at $208 \mathrm{~nm}\left(\pi \rightarrow \pi^{*}\right)$ and $222 \mathrm{~nm}\left(n \rightarrow \pi^{*}\right)$ and a positive maximum at approximately $190 \mathrm{~nm}\left(\pi \rightarrow \pi^{*}\right)$ (orange) [87]. In "pure" $\beta$-sheet structures, a negative signal is observed at near $215 \mathrm{~nm}\left(n \rightarrow \pi^{*}\right)$ and a positive signal at about $196 \mathrm{~nm}\left(\pi \rightarrow \pi^{*}\right)$ [87]. The CD spectrum of the disordered structures stands out clearly. Here, a positive CD band at $212 \mathrm{~nm}$ and a negative one at $195 \mathrm{~nm}$ are characteristic [75,85]. 
A

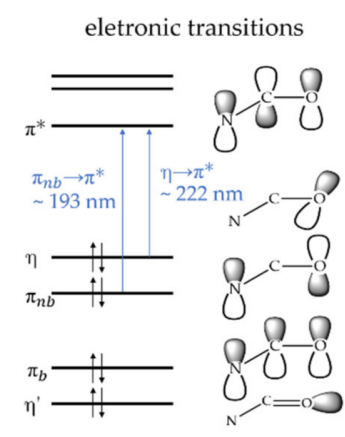

B

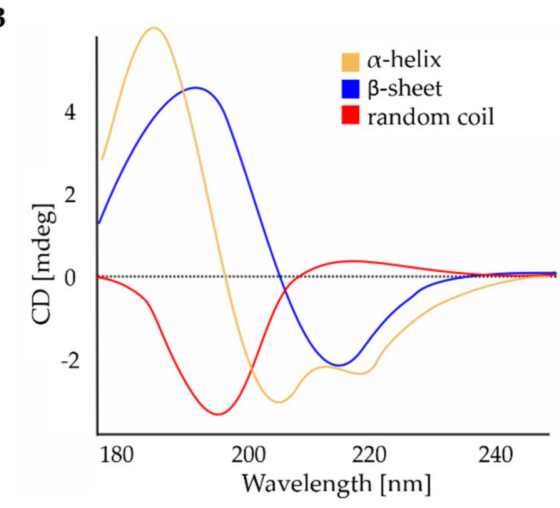

Figure 10. (A) Energy level diagram with electronic transitions of a peptide bond in the far UV region. Bonding, non-bonding, and antibonding p-orbitals $\left(\pi_{b}, \pi_{n b}\right.$ and $\left.\pi^{*}\right)$ and two free electron pairs at the oxygen $\left(\eta\right.$ and $\left.\eta^{\prime}\right)$ are shown $[75,76]$. (B) Characteristic CD spectra in the far UV region of "pure" $\alpha$-helix, $\beta$-sheet, and disordered structures, redrawn from [85].

For quantification of the secondary structural elements of a protein sample, the far-UV $\mathrm{CD}$ spectrum obtained is understood as the empirical sum of the fractional multiples of the characteristic spectra for each type of secondary structure type [86,88-90]. For quantitative analysis of the $C D$ spectrum of a protein and estimation of the proportions of secondary structures, the experimentally obtained far-UV CD spectrum of a protein is understood as a linear combination of the three most abundant secondary structures ( $\alpha$-helix, $\beta$-sheet, and random coil) at a given wavelength. In reality, combinations or superpositions of several CD spectra of the respective secondary structure types are obtained. As there is a correlation between the far-UV CD spectra and the secondary structure of the proteins, $\mathrm{CD}$ spectroscopy can be used to determine the proportions of secondary structures and to study changes in secondary structure [86,88-90].

The far-UV spectra of the native and unmodified $\alpha$-LA (Figure 3, black and red curves) showed a positive maximum at $190 \mathrm{~nm}$ and two negative bands at approximately 208 and $220 \mathrm{~nm}$, which is characteristic of an $\alpha+\beta$ class protein [60,91]. In agreement with the results of other studies, quantitative determination of the amount of secondary structures confirmed that native $\alpha$-LA consists of 30\% $\alpha$-helix, $12 \% \beta$-sheet, and $58 \%$ of regions with low structural complexity (Table 2) $[36,92,93]$. It has been described in the literature that the secondary structure of native $\alpha$-LA consists of $26 \% \alpha$-helices, $14 \% \beta$-sheets, and $60 \%$ disordered structures [36], and the tertiary structure consists of two domains [36,37,94]. Although a large cleft separates the large $\alpha$-domain from the small $\beta$-domain, they are held together by an ionic calcium bond and the four disulfide bridges $[35,36,95]$. Three pH-stable $\alpha$-helices (H1 (5-11), H2 (23-34) and H3 (86-98)) and a pH-dependent $\alpha$-helix (H4 (105-110) and two smaller 310 helices: (h1 (18-20) and h3 (115-118)) build the large $\alpha$-domain, with the flexible loop region at positions 105-110 adopting a helical structure for $\mathrm{pH}$ values between 6.5 and 8 [96]. The $ß$-domain consists of three antiparallel $ß$-sheets (S1 (41-44), S2 (47-50), S3 (55-56)), a short 310 helix (h1b (18-20), h2 (77-80), h3c (115-118)), and loops and disordered structures $[32,37,95,97]$.

The unmodified $\alpha$-LA control also showed comparable amounts of secondary structural elements, suggesting that neither the synthesis nor the work-up conditions have an effect on the structural properties of the protein. While the values of the molar ellipticity of the positive band and the negative bands between the BITC- $\alpha$-LA derivative "low" and the control samples showed no significant differences (Figure 3, dark green curve), the quantitative determination of the secondary structures of the BITC- $\alpha$-LA derivative "low" showed a slight decrease in the $\alpha$-helical structure to $24 \%$ and an increase in the $\beta$-sheet content to $19 \%$. The amount of lower complexity secondary structures remained almost constant. As a result of increasing the concentration of BITC used to synthesize the BITC- $\alpha$-LA derivatives "medium" and "high," derivatization with BITC caused a decrease in band intensity at all wavelengths (Figure 3, light green and yellow curves). Increasing derivatization with 
BITC caused a further decrease in the $\alpha$-helix content to 20 and $17 \%$, with a concomitant increase in the $\beta$-sheet structure content to 25 and $28 \%$. The content of disordered structures remained unchanged. The results showed an influence on the secondary structure as a consequence of the BITC conjugation. As the degree of derivatization increased, a significant perturbation or successive change in the secondary structure of $\alpha$-LA was documented. In summary, with increasing input concentration of BITC, a steady loss of $\alpha$-helical fractions with a concomitant increase in the fractions of $\beta$-sheets was observed. Comparable results were recently obtained in a study investigating the conjugation of $\alpha$-LA with polysaccharides [98]. The spectra of a pure and a conjugated protein were recorded by far UV-CD spectroscopy. Depending on the polysaccharides used, different degrees of reductions in $\alpha$-helix fractions were observed [98]. Likewise, protein modification with, for example, polyphenols, oligosaccharides, and allicin showed a change in the secondary structure or conformation of proteins [99-101]. Rade-Kukic et al. (2011) also observed a change in secondary and tertiary structure depending on the amount of AITC bound to $\beta$-LG [1]. According to Kelly et al. (2005), an increase in molar ellipticities characteristic of $\alpha$-helices may imply higher structural compactness. Conversely, the decrease in molar ellipticity of BITCtreated proteins would indicate less dense structures [73]. Similar findings were provided by the work of Das et al. (2014), who modified lysozyme, a structurally similar protein to $\alpha$ LA, with different concentrations of ellipticin and then investigated the secondary structure using far-UV CD spectroscopy. By decreasing the band intensity between 208 and $230 \mathrm{~nm}$, it was concluded that the typical $\alpha$-helical structure of the protein was destabilized and unfolded as a result of the conjugation of ellipticin [102]. Chemical modification such as acetylations and sulfamidations as well as reactions with other secondary plant compounds such as polyphenols also resulted in similar restructuring and disruption of the secondary structure of the proteins, as reported by Gerbanowski et al. (1999), Schwenke et al. (2000), and Rawel et al. (2002, 2003) [60,91,103,104]. Sun et al. (2018) demonstrated that the addition of tetracycline hydrochloride $(\mathrm{TCH})$ caused a loosening of the protein structure of lactoferrin. The CD spectra showed a decrease in negative band intensity as a result of the increasing degree of derivatization with TCH. They explained the reduction by breaking of hydrogen bonds due to TCH conjugation of lactoferrin and hypothesized that the altered secondary structure might also affect physiological functions [51].

It should be mentioned that the analysis of the amounts of $\beta$-sheets is complicated because this secondary structure produces only a relatively weak signal and cannot always be clearly differentiated from the signals of unfolded or disordered regions. Although it is not possible to obtain more detailed information about the exact secondary structure of proteins using CD spectroscopy, the additional value of the method is the ability to indicate denaturation or a structural change resulting from chemical modification and the ability to estimate the amounts of secondary structures, including $\alpha$-helix, $\beta$-sheet, and disordered structures. For such studies, comparison with a CD spectrum of the native protein is indispensable $[48,105]$. More sensitive methods that can decipher smaller changes at the molecular level include fluorescence techniques [48,105].

\subsection{Influence of BITC Conjugation on Temperature-Induced Conformational Changes of $\alpha-L A$}

The results of the CD experiments of the untreated $\alpha$-LA control (Figure 4a) showed a decrease in the molar ellipticities of the double minimum and an increase in the molar ellipticities of the maximum at $190 \mathrm{~nm}$ in the temperature range from 30 to $50^{\circ} \mathrm{C}$, which could be indicative of higher structural compactness in the secondary structure according to Kelly et al. (2005) [73]. By further increasing the temperature $\left(60-80{ }^{\circ} \mathrm{C}\right)$, a decrease in the minimum at $208 \mathrm{~nm}$ and the maximum at $190 \mathrm{~nm}$, as well as a simultaneous increase in the minimum at $222 \mathrm{~nm}$, were observed. These observations are indicative of a loss or a change of the secondary structure due to the increasing temperature.

Similar results were documented in the work of Lam et al. (2015). Although their focus was on the thermal pretreatment of the protein $\alpha$-LA and subsequent study of the effect using CD spectroscopy, certain parallels are noted. They were able to observe a 
decreased mean ellipticity curve when the temperature was increased from 25 to $65^{\circ} \mathrm{C}$, suggesting increased order in the secondary structures of $\alpha$-LA. By further increasing the temperature to $95^{\circ} \mathrm{C}$, a loss of secondary structure was assumed, which was reflected in an increase in the mean ellipticity curve in the wavelength range from 190 to $230 \mathrm{~nm}$. They hypothesized that the protein underwent increased conformational entropy at temperatures up to $65^{\circ} \mathrm{C}$, which would result in the higher ordering of the polypeptide chains, whereas denaturing processes predominated at temperatures of $95^{\circ} \mathrm{C}$. Due to the fact that hydrogen bonds are broken at these temperatures, loss of secondary structure may consequently occur [28]. Another study confirmed that $\alpha$-LA denatures irreversibly at temperatures above $90^{\circ} \mathrm{C}$ [106].

For quantification of the $\alpha$-helical portion of a protein, for example, CD data of molar ellipticity at $222 \mathrm{~nm}$ can be used, where the $\alpha$-helical structure has a characteristic minimum ellipticity [85,107]. When comparing signals at a wavelength of $222 \mathrm{~nm}$, differences between a folded and an unfolded protein can be large. However, an analogous method for estimating $\beta$-sheet or random coil structures does not exist $[90,108]$. For the derivatives (Figure $4 \mathrm{~b}-\mathrm{d}$ ), an increase in the molar ellipticity of the minimum at $222 \mathrm{~nm}$ and a decrease in the maximum at $190 \mathrm{~nm}$ could already be noted at temperatures above $40^{\circ} \mathrm{C}$, suggesting a decrease in the $\alpha$-helical fraction due to the temperature increase. In the $\alpha$-LA control, the described effects could be observed only above a temperature of $60^{\circ} \mathrm{C}$.

Although the secondary structure appears relatively stable, it can be hypothesized that in addition to a dominant loss of the $\alpha$-helical structure, an increase in the fractions of random coil or extended structures also affects the minimum at $209 \mathrm{~nm}$. Thus, the decrease in the molar ellipticity of the minimum at $209 \mathrm{~nm}$ at temperatures above $50{ }^{\circ} \mathrm{C}$ for the $\alpha$-LA control and for the BITC- $\alpha$-LA derivative "small" could indicate a change in secondary structure. Considering Figure 10B, which shows the characteristic CD spectra of pure secondary structures, this relationship can be better visualized. While the fraction of the yellow curve (characteristic CD spectrum for proteins with pure $\alpha$-helical structure) is decreased, the fraction of the blue (characteristic CD spectrum for proteins with pure $\beta$-sheet structure) and red (characteristic CD spectrum for proteins with random coil structure) curves can be increased. Presumably, this state is similar to the state that the BITC- $\alpha$-LA derivatives "medium" and "high" already have with less thermal energy already at room temperature. The BITC- $\alpha$-LA derivatives "medium" and "high" have overall lower band intensities and thus appear to be less "stably" folded than the $\alpha$-LA control and the BITC- $\alpha$-LA derivative "low".

It can be summarized that with an increasing degree of derivatization, the differences of the molar ellipticities become increasingly smaller as a function of temperature. As already found out in Section 2.2, a change in the secondary structure fractions is evident with increasing BITC modification, although this difference between the samples could be increasingly lost at higher temperatures due to partial denaturation.

\subsection{Influence of BITC Conjugation on Surface Hydrophobicity of $\alpha$-LA}

A commonly used extrinsic fluorescent dye is ANS, which is from the sulfonic acid group and is used to study unfolding or folding intermediates, detect protein aggregates, characterize changes in protein conformations, and measure surface hydrophobicity. Interaction of ANS with proteins is possible in two ways. On the one hand, there can be electrostatic interactions between the sulfonate group of ANS with positively charged side chains of the protein, and on the other hand, the interaction of ANS can occur via hydrophobic interactions with the hydrophobic regions on the surface of proteins [1,52-58]. While ANS does not fluoresce in aqueous polar solutions, the dye shows a blue shift of the fluorescence emission maximum and an increase in fluorescence intensity in apolar organic (hydrophobic) solutions or when bound to, for example, proteins [52,56,58,109-112].

The results in Figure 5 showed that unmodified $\alpha$-LA exhibited low ANS fluorescence emission, suggesting that ANS molecules interacted with hydrophobic regions on the surface of the protein. Globular, water-soluble proteins in the native state, such as $\alpha$-LA, 
are thought to have low affinity or accessibility for ANS molecules due to the orientation of the hydrophobic protein side chains into the interior of the molecule. Although the hydrophobic core of most protein is typically shielded from the organic environment by a rigid tertiary structure, isolated hydrophobic groups may occur on the protein surface or be exposed in crevices so that even native globular proteins may have a few hydrophobic binding sites on the protein surface for ANS molecules and produce low fluorescence intensity $[109,110,113]$. This assumption is supported by previous results showing that native $\alpha$-LA can bind up to five molecules of an ANS derivative [35,114]. In work described by Singh et al. (2006), it was added that the binding of ANS to the native state of $\alpha$-LA was not very strong due to the lack of hydrophobic interactions [114].

Thus, while in the native, untreated state of $\alpha$-LA, the hydrophobic side chains are mainly concentrated in the protein interior and are of limited availability to the ANS molecules, and an increasing ANS fluorescence intensity was documented with increasing degree of derivatization, suggesting that BITC conjugation exposed increased hydrophobic regions on the surface of $\alpha$-LA and allowed them to interact with the ANS molecules. The resulting increase in binding affinity to ANS explained the increase in ANS fluorescence as a function of the concentration of BITC used. In summary, BITC conjugation resulted in a change of the hydrophobic character, more specifically, an increase in the surface hydrophobicity of $\alpha$-LA [9].

Previous research regarding the change in surface hydrophobicity of other proteins showed similar effects after chemical modification. For example, a correlation between the conformational change and the increase in surface hydrophobicity of concanavalin A (ConA) as a result of the conjugation of sodiumdodecylsulfate (SDS) was documented [115]. Additionally, modifications of proteins, such as BSA, casein, and whey protein isolates, with citric acid or acyl groups (acylations) led to an increase in surface hydrophobicity with increasing degree of derivatization, which was attributed to a change in protein conformation and subsequent exposure of hydrophobic groups to the protein surface [116,117]. The relationship between the exposure of hydrophobic groups due to denaturation of proteins and the increase in surface hydrophobicity was described as early as 1980 by Kato et al. [118].

Wilde et al. (2016) studied the interaction of $\beta$-LG with allicin and diallyl disulfide using RP-HPLC and far UV-CD spectroscopy to detect changes in surface hydrophobicity and secondary structure. They described the conjugation of the ligands and the resulting change in the secondary structure or loosening of the globular protein structure as the cause of the increased surface hydrophobicity of the protein [99]. In a follow-up study, Keppler et al. (2017) found that under neutral conditions, ANS binding was increased as a result of AITC conjugation to whey protein isolate (WPI). The increase in hydrophobic surface area was probably caused by changes in the conformation of WPI as a result of conjugation of the hydrophobic ligand AITC [9]. In another study, AITC conjugation to the whey protein $\beta-\mathrm{LG}$ was investigated [1]. The results of ANS measurements initially showed an increase in fluorescence intensity under neutral conditions, whereas there was a decrease in fluorescence emission as the degree of derivatization increased. The initial increase in ANS fluorescence was consistent with RP-HPLC results, which also showed an increase in hydrophobicity. The subsequent decrease in ANS fluorescence intensity due to increasing AITC modification was attributed to the change in protein conformation confirmed by CD experiments. The authors concluded that the increased surface hydrophobicity resulted from the AITC-induced conformational changes. Furthermore, improved emulsifying and foaming properties of the protein were obtained as a result of AITC conjugation to $\beta$-LG [1]. Similar effects of chemical modification on emulsifying and foaming properties of WPI were reported by Li et al. (2018) [116].

While conjugation with phenols on BSA resulted in a decrease in hydrophobic surface area and improved solubility [91], phenol adducts with myoglobin showed opposite effects. The myoglobin-phenol conjugates showed increased hydrophobicity and thus decreased 
solubility $[119,120]$. Another study confirmed the correlation between increased surface hydrophobicity and decreased solubility by ANS fluorescence measurements [59].

Considering that the electrophilic ITC preferentially react with amino and thiol groups of the protein side chains, it is reasonable to assume that as a consequence of the introduction of the hydrophobic ligand BITC or by blocking the free amino and thiol groups, a decrease in polarity and a loss of charge cause the increase in surface hydrophobicity. In addition, the ITC-induced change in secondary structure favors the exposure of hydrophobic regions on the protein surface [1].

\subsection{Influence of BITC Conjugation on the Hydrodynamic Radius of $\alpha$-LA}

Dynamic light scattering (DLS) is an analytical method for determining the size and size distribution and monitoring the aggregation behavior and ligand binding of proteins and other biomolecules, usually in the nanometer to submicrometer range [121-123]. The method measures the Brownian molecular motion of particles or molecules dissolved or dispersed in a liquid and uses the information to calculate the hydrodynamic radius [121-125].

Determination of the mean hydrodynamic radius of the unmodified $\alpha$-LA control yielded a value of $1.76 \pm 0.24 \mathrm{~nm}$, which is comparable to previously published values $[95,126,127]$. For example, Delavari et al. (2015) were able to determine a hydrodynamic diameter of $3.6 \mathrm{~nm}$ for $\alpha$-LA [95]. As a result of the conjugation of BITC to $\alpha$-LA, a significant increase in the hydrodynamic radius to a maximum of $89.37 \pm 14.86 \mathrm{~nm}$ was observed regardless of the concentration of BITC used. Furthermore, multiple signals and broader peaks were observed, indicating inhomogeneous and highly polydisperse protein solutions.

Similar effects on the hydrodynamic radius of proteins as a result of interaction with ligands were documented by Delavari et al. (2015) and Abasi et al. (2014) [95,128]. Thus, the interaction of $\alpha$-LA with vitamin D3 showed an increase in hydrodynamic diameter from 3.6 to $125 \mathrm{~nm}$. Furthermore, they found an altered secondary structure and increased surface hydrophobicity as a result of the interaction [95]. Abasi et al. (2014) reported a nanoparticle consisting of vitamin D3 and homogenized whey protein isolate with similar size $[95,128]$. Presumably, the increase in particle size is due to the encapsulation of vitamin D3 to the $\alpha$-LA [128] or hydrophobic intramolecular interactions between the protein molecules [129]. It has been suggested that upon binding of vitamin D3 to $\alpha$-LA, hydrophobic side chains are exposed, which may allow hydrophobic interactions between protein molecules, leading to larger complexes [129]. A further study showed that when oleic acid was used as a hydrophobic ligand, the $\alpha$-LA derivatives were larger than those of other proteins [126].

It should be noted that in DLS, an intensity-weighted hydrodynamic radius is determined, and this is strongly dominated by larger particles/molecules at the expense of smaller particles/molecules $[1,130]$. That is, due to the fact that the intensity of the scattered light increases proportionally to the sixth power of the diameter, the scattered light from a small population of large particles/molecules overlaps the scattered light from smaller particles to such an extent that they can no longer be detected, leading to biased radius distributions [131]. For a complementary quantitative analysis of particle sizes in polydisperse solutions, alternative methods, such as size exclusion chromatography, should be used [130].

\subsection{Influence of BITC Conjugation on Tryptic Digestion of $\alpha$-LA}

As trypsin preferentially cleaves after the amino acids lysine and asparagine [132] and ITC has been shown to react with e-amino groups of lysine side chains several times $[43,45,67,69]$, it is reasonable to assume that BITC modification of the amino group of the amino acid lysine could lead to masking of trypsin cleavage sites/steric hindrance of tryptic hydrolysis $[7,17,42,132]$. This assumption can be confirmed by the present results, which showed that more elongated modified peptide sequences were detected with increasing derivatization. Furthermore, this assumption was supported by the fact that 
the tryptic hydrolysis of the BITC-modified $\alpha$-LA derivatives yielded a higher amount of peptides compared to that of the native $\alpha$-LA control sample, again emphasizing that as a result of the conjugation of BITC to the amino groups of lysine, the protein is protected from subsequent tryptic hydrolysis $[7,65]$. The present findings were in agreement with the results of previous studies, which also showed that tryptic hydrolysis was inhibited for ITC-modified $\beta$-lactoglobulin [7], egg white proteins, myoglobin, legumin [133], and glycosylated proteins $[134,135]$.

Moreover, the results of mass spectrometry analysis showed that the BITC-modified peptides eluted at later retention times, which was consistent with the experimentally obtained ANS fluorescence results, indicating higher hydrophobicity. Similar results were shown in the work of Wilde et al. (2016), who also linked an increase in retention time to an increase in hydrophobicity as a result of the modification of $\beta$-LG by allicin and diallyl disulfide [99].

In agreement with previous results, it was repeatedly shown that a higher degree of derivatization could be achieved with increasing input concentration of BITC, resulting in successive blocking of several tryptic cleavage sites of $\alpha$-LA and consequently yielding longer peptides [7].

It is conceivable that via the classical CID fragmentation method, a clear localization of the modification is hardly possible due to the complete cleavage of the BITC group. In contrast to CID, newer fragmentation techniques are based on a destabilization of the peptide ions via a reaction with electrons (electron-capture dissociation, ECD) or radical anions (electron-transfer dissociation, ETD) [136]. ECD and ETD are particularly used to characterize labile protein modifications, preferentially generating c- and z-fragment ions. A key advantage of these methods is that modifications that are unstable under collision-induced fragmentation remain intact, allowing unambiguous localization. Thus, labile histidine and lysine modifications/phosphorylations can be identified [137].

\section{Materials and Methods}

\subsection{Materials}

1,4-Dioxane, acetonitrile, ethanol, disodium hydrogen phosphate, hydrochloric acid $(32 \%)$, isoleucine, sodium dihydrogen phosphate, sodium hydrogen carbonate, and dialysis membranes (regenerated cellulose, molecular weight cutoff $<3.5 \mathrm{kDa}$ ) were obtained from Carl Roth GmbH \& Co. KG, Karlsruhe, Germany. Bovine $\alpha$-lactalbumin ( $\alpha$-LA) as model protein, benzyl isothiocyanate (98\%), dithiothreitol (DTT), $n$-acetyl-L-cysteine, o-phthalaldehyde, 8-Anilino-1-naphthalenesulfonic acid ammonium salt, and trypsin from porcine pancreas were purchased from Sigma-Aldrich $\mathrm{GmbH}$, Steinheim, Germany. Formic acid and urea were purchased from Merck KGaA, Darmstadt, Germany. $\mathrm{C}_{18}$ solid-phase extraction cartridges $(1 \mathrm{~mL}, 100 \mathrm{mg}$ ) were purchased from Macherey-Nagel GmbH \& Co. KG, Düren, Germany. All solvents were of HPLC grade; otherwise, ACS grade was used. Water was double-distilled $\left(\mathrm{ddH}_{2} \mathrm{O}\right)$.

\subsection{Methods}

\subsubsection{Preparation of ITC- $\alpha$-LA Conjugates}

The preparation of the ITC-protein conjugates was carried out according to the instructions of Spöttel et al. [47]. Briefly, for the synthesis of ITC-protein conjugates, $\alpha$-LA protein was first dissolved in water $(0.714 \mathrm{mM})$ and then mixed with three to six different concentrations of BITC ranging from 0 to $113 \mathrm{mM}$ (Table 7). For this purpose, the appropriate amount of BITC was dissolved in 1,4-dioxane. After the incubation for $20 \mathrm{~h}$ at $37^{\circ} \mathrm{C}$, the reaction solution was dialyzed overnight and subsequently lyophilized for removing as much as residual BITC. To prevent cold denaturation, for lyophilization, the samples were first frozen in liquid nitrogen and then transferred to a laboratory freeze dryer (Christ RVC 2-25 CDplus, Martin Christ Gefriertrocknungsanlagen GmbH, Osterode am Harz, Germany). In order to make a comparison between BITC-treated and untreated $\alpha$-LA and to be able to exclude any influence of the synthesis and work-up conditions, control sam- 
ples were prepared and treated in the same way as the modifications except that no BITC was added. The freeze-dried samples were stored at $-20^{\circ} \mathrm{C}$ until analysis. Depending on the subsequent analysis, the freeze-dried sample was dissolved in a suitable solvent.

Table 7. Summary of synthesis parameters to represent BITC protein conjugates and control sample.

\begin{tabular}{cccc}
\hline Sample & $\mathbf{c}(\alpha$-LA) $(\mathbf{m M})$ & $\mathbf{c ( B I T C )}(\mathbf{m M})$ & B $_{\text {BITC } / \alpha \text {-LA }}$ \\
\hline$\alpha$-LA control & 0.07 & - & 0 \\
BITC- $\alpha$-LA derivate "minimal" & 0.07 & 0.6 & 10 \\
BITC- $\alpha$-LA derivate "minor" & 0.07 & 1.9 & 25 \\
BITC- $\alpha$-LA derivate "low" & 0.07 & 3.8 & 50 \\
BITC- $\alpha$-LA derivate "medium" & 0.07 & 38 & 500 \\
BITC- $\alpha$-LA derivate "high" & 0.07 & 75 & 1000 \\
BITC- $\alpha$-LA derivate "very high" & 0.07 & 113 & 1500 \\
\hline
\end{tabular}

\subsubsection{Determination of Free Amino Groups Using O-Phthaldialdehyde}

A commonly used reagent for the determination of free $\alpha$ - and $\varepsilon$ - amino groups is ortho-phthaldialdehyde (OPA), which reacts with primary amino groups in the presence of a thiol compound such as N-acetyl-L-cysteine (NAC) to form a 1-alkylthio-2-alkylsubstituted isoindole. The fluorescent isoindole can absorb light at a wavelength of $340 \mathrm{~nm}$ and has been quantified spectrophotometrically [1,138-143].

For the quantitative determination of free $\alpha$ - and $\varepsilon$-amino groups before and after conjugation of BITC, the method using OPA was performed [144]. For this purpose, the protocol provided by the Interchim Deutschland $\mathrm{GmbH}$ (Mannheim, Germany) was used as a basis for the measurement of free amino groups in proteins, which was slightly adapted [145]. Major differences were that instead of $\alpha$-acetyl-lysine, isoleucine was used as a standard, and instead of mercaptoethanol, $\mathrm{N}$-acetyl-L-cysteine was used as a thiol component. The isoleucine used contains one amine per molecule, allowing a ratio of labeling to be determined.

Briefly, for the quantitative determination of free amino groups of unmodified and BITC-modified $\alpha$-LA, six different modifications and a control sample were prepared as described previously (Table 7, Section 4.2.1). The lyophilized samples were dissolved in $2 \mathrm{~mL}$ carbonate buffer $(50 \mathrm{mM}, \mathrm{pH} 10)$ and each diluted 1:5 $(71.4 \mu \mathrm{M})$. To prepare the OPA reagent, $5 \mathrm{mg}$ OPA and $11.7 \mathrm{mg} \mathrm{N}$-acetyl-L-cysteine (NAC) were dissolved in $100 \mu \mathrm{L}$ ethanol followed by $10 \mathrm{~mL}$ carbonate buffer $(50 \mathrm{mM}, \mathrm{pH} 10)$. The OPA reagent was protected from direct light and used within two hours. For the external calibration series, a $10 \mathrm{mM}$ isoleucine standard solution was prepared in carbonate buffer followed by a serial dilution of $10-522 \mu \mathrm{M}$ of the standard solution in carbonate buffer. The preparation of the calibration series was performed with seven calibration points. A total of $100 \mu \mathrm{L}$ of OPA reagent was added to $100 \mu \mathrm{L}$ of each of the calibration solutions and the protein solutions to be examined and incubated for two minutes at $23{ }^{\circ} \mathrm{C}$ in a $96-$-well microtiter plate. Transparent plates were used for the measurement. Subsequently, the absorbance was determined photometrically at a wavelength of $340 \mathrm{~nm}$, using a Synergy ${ }^{\mathrm{TM}}$ HT (BioTek Instruments Inc., Vermont, VT, USA). A comparison was made between the calculated free amino groups of the control sample and those of the BITC-modified derivatives. For this purpose, the concentration of free amino groups of the control sample was normalized to $100 \%$. The assay of accessible amino groups was performed in triplicate.

\subsubsection{Investigation of Secondary Structure by Far-UV CD Spectroscopy}

CD spectroscopy was used to evaluate the influence of BITC conjugation on the secondary structure of $\alpha$-LA. In order to estimate and compare the composition of the secondary structures of the untreated $\alpha$-LA control and the BITC- $\alpha$-LA derivatives "low," "medium," and "high," CD experiments were performed using a Jasco J-815 spectrometer (Jasco Inc., Mary's Court, MD, USA).

After lyophilization, the samples under investigation were dissolved in $1 \mathrm{~mL}$ of $0.01 \mathrm{M}$ sodium phosphate buffer $(\mathrm{pH} 8)$ and diluted to a final protein concentration of 
approximately 16-18 $\mu \mathrm{M}$. When selecting the buffer, it is important to ensure that the buffer used has the lowest possible self-absorption in the short wavelength region to minimize signal interference. In addition, a native protein control was measured to exclude any impact of synthesis and purification on the protein structure. For this purpose, $1 \mathrm{mg}$ of $\alpha$-LA was weighed, dissolved in the sodium phosphate buffer, and diluted.

The CD experiments were performed under permanent nitrogen flow to protect the optical components of the spectropolarimeter from ozone gas. Ozone gas can be formed from atmospheric oxygen under UV irradiation, which can attack the mirror surfaces and consequently reduce the reflectivity and longevity of the mirrors and reduce the efficiency in focusing the light through the monochromator. In addition, molecular oxygen absorbs below $195 \mathrm{~nm}$, but since this spectral region is particularly important for estimating the secondary structure of proteins, the lower the wavelength during the measurement, the greater the flux rate of nitrogen must be to minimize oxygen absorption.

Measurements were performed in the far-UV range between 185 and $260 \mathrm{~nm}$ in a quartz cell of $1 \mathrm{~mm}$ slice thickness, a step size of $0.1 \mathrm{~nm}$ per data point, and a scanning speed of $100 \mathrm{~nm} / \mathrm{min}$. The temperature was set to $20^{\circ} \mathrm{C}$ for all measurements using a Peltier element (Jasco Inc., Mary's Court, MD, USA). For each sample, 15 spectra were recorded and averaged. Then, the averaged ellipticity of the buffer solution was subtracted from the CD data of all samples. The measured ellipticities were scaled and expressed as molar ellipticity (MME) in deg $\mathrm{cm}^{2} \mathrm{dmol}^{-1}$ :

$$
[\theta]=\frac{\theta \cdot M}{d \cdot c \cdot 100,000}
$$

where $\theta$ is the ellipticity in mdeg, $M$ is the molecular weight of the protein in $\mathrm{g} / \mathrm{mol}, d$ is the path length of the cuvette in $\mathrm{cm}$, and $c$ is the concentration of the protein in $\mathrm{g} / \mathrm{mL}$.

The experimentally obtained spectra provided a fingerprint of the secondary structure composition of untreated and BITC-treated $\alpha$-LA.

Online services can be used to facilitate the analysis of proteins. To evaluate the data, reference spectra of proteins with known 3D structures listed in an available database (the protein circular dichroism data bank, or PCDDB) are used. In addition, the CD spectroscopic data were analyzed using the DichroWeb online server (http:/ / dichroweb.cryst. bbk.ac.uk/html/links.shtml; accessed on 10 October 2021). DichroWeb provides several algorithms to deconvolute CD spectra. These include, for example, the K2d method [146], which has integrated protein reference data [147]. The K2D method of the Dichroweb server was used to deconvolute the CD data and determine the relative secondary structure composition of each sample. Thus, based on a far-UV CD spectrum of a protein, the percentages of the respective secondary structures were calculated [75].

\subsubsection{Investigation of Temperature-Induced Conformational Changes Using Far UV CD Spectroscopy}

For the analysis of the temperature-induced change in the secondary structures of the untreated $\alpha$-LA control and the BITC- $\alpha$-LA derivatives "low," "medium," and "high," the samples were prepared, measured, and analyzed according to Section 4.2.3. Major deviation in the performance was that the CD spectra were recorded using the Peltier element (Jasco, $21601 \mathrm{MD}, \mathrm{USA}$ ) in a temperature range of $30-80^{\circ} \mathrm{C}$ with an increment of $2{ }^{\circ} \mathrm{C} / \mathrm{min}$. To investigate the temperature stability of the protein solutions, the temperature was increased by $2{ }^{\circ} \mathrm{C}$ per minute to adjust and stabilize the temperature for the next measurement.

\subsubsection{Investigation of Surface Hydrophobicity Using ANS Fluorescence}

To measure the surface hydrophobicity of untreated and BITC-treated $\alpha$-LA, 8-anilinonaphthalene-1-sulfonic acid was used as hydrophobic fluorescent probe that interacts with hydrophobic/nonpolar regions on the protein surface and generates a fluorescent signal $[56,110,118,148]$. The measurements were performed following the work of Kato et al. [118] and Lam et al. [149]. 
BITC-treated and untreated protein samples were prepared as previously described. After lyophilization, the freeze-dried samples were dissolved in $2 \mathrm{~mL}$ of phosphate buffer $(0.01 \mathrm{M}, \mathrm{pH} 8)$ to give a protein concentration of $0.035 \mathrm{mM}$. To prepare the ANS reagent, $29.0 \mathrm{mg}$ of ANS ammonium salt was dissolved in $10 \mathrm{~mL}$ of demineralized water $(9.17 \mathrm{mM})$. After aliquoting the protein solutions into three parts of $0.4 \mathrm{~mL}$ each, $77.9 \mu \mathrm{L}$ of ANS reagent was added to each part, resulting in a protein/ANS concentration ratio of 1/50. The protein solutions were incubated for five minutes in the absence of light. Subsequently, the measurement was performed using a 384-well black corning flat bottom plate on the SpectraMax ${ }^{\circledR}$ M3 fluorescence microplate reader from Moleculare Devices LLC (San Jose, CA, USA). For this purpose, $80 \mu \mathrm{L}$ of each sample solution was pipetted three times into the microplate, and then the fluorescence was measured at an excitation wavelength of $390 \mathrm{~nm}$ in the wavelength range of $430-600 \mathrm{~nm}$. The surface hydrophobicity was determined in triplicate for each sample.

\subsubsection{Determination of the Hydrodynamic Radius Using Dynamic Light Scattering}

Dynamic light scattering (DLS) can be used to obtain information on the aggregation behavior, hydrodynamic radius, and monodispersity of BITC-modified and unmodified $\alpha$-LA (derivatives). DLS measurements were performed using a SpectroSize300 instrument with an implemented $660 \mathrm{~nm}$ wavelength diode laser (Xtal-Concepts $\mathrm{GmbH}$, Germany). After synthesis, the unmodified $\alpha$-LA control sample and the BITC- $\alpha$-LA derivatives "low," "medium," "high," and "very high" were centrifuged at 16,000 $\times \mathrm{g}$ for $10 \mathrm{~min}$ and then transferred to a quartz cuvette without air bubbles. The measurement was carried out at a temperature of $20^{\circ} \mathrm{C}$ and a scattering angle of $90^{\circ}$ (viscosity of the sample: $2.18 \mathrm{cP}$; refractive index: 1.33). For each sample, 20 DLS measurements for $20 \mathrm{~s}$ per measurement were performed. The hydrodynamic radius was calculated as an average value from the 20 scans. The particle size distribution was calculated using the CONTIN algorithm, taking into account the viscosity of the medium. The diffusion coefficient $\mathrm{D}$ was determined based on an autocorrelation analysis of the scattered light intensity governed by translational particle diffusion, and the average hydrodynamic radius was then calculated using the Stokes-Einstein equation:

$$
R_{H}=\frac{k T}{6 \pi \eta D}
$$

where $R_{H}$ is the hydrodynamic radius $(\mathrm{m}), k$ is the Boltzmann constant $\left[1.380642 \times 10^{-23} \mathrm{JK}^{-1}\right]$, $T$ is the absolute temperature (K), $\eta$ is the viscosity of the solution $\left[\mathrm{kg} \mathrm{m}^{-1} \mathrm{~s}^{-1}\right]$, and $D$ is the translational diffusion coefficient $\left[\mathrm{m}^{2} \mathrm{~s}^{-1}\right][150]$.

\subsubsection{Tryptic Hydrolysis of Unmodified and BITC-Modified $\alpha$-LA}

Tryptic hydrolysis of the freeze-dried BITC-treated and untreated protein samples was performed according to the instructions described by Spöttel et al. [47]. For this purpose, the freeze-dried samples were resolved in $50 \mu \mathrm{L}$ of $6 \mathrm{M}$ aqueous urea followed by addition of $100 \mathrm{mM}$ DTT (in $100 \mathrm{mM}$ sodium hydrogen carbonate) to cleave disulfide bridges. After incubation at $60^{\circ} \mathrm{C}$ for $10 \mathrm{~min}, 425 \mu \mathrm{L} 100 \mathrm{mM}$ sodium hydrogen carbonate (in water) was added. Tryptic hydrolysis was performed by adding the trypsin solution $(1 \mathrm{mg} / \mathrm{mL}$ in $0.1 \mathrm{mM} \mathrm{HCl})$ to the protein solution at a ratio of $1: 100$ for $16 \mathrm{~h}$ at $37^{\circ} \mathrm{C}$. Subsequently, the enzymatic hydrolysis was terminated by the addition of $0.2 \%$ formic acid. Solid-phase extraction was used to purify the digested samples. Therefore, the chromatography material was first conditioned and equilibrated with $60 \% \mathrm{ACN}$ (in water) and $0.2 \%$ formic acid (in water). Subsequently, the samples were applied, rinsed with $0.2 \%$ formic acid (in water), and then eluted with $60 \%$ ACN (in water). Finally, the samples were concentrated with gaseous nitrogen and dissolved in $0.2 \%$ formic acid (in water) for further analysis. 


\subsubsection{LC-ESI-MS/MS of Unmodified and BITC-Modified $\alpha$-LA}

Chromatographic separation of tryptic untreated and BITC-modified protein hydrolysates was performed on a reversed-phase HPLC column (Nucleodur, $5 \mu \mathrm{m}$ C8 $100 \AA$ A, $150 \times 2 \mathrm{~mm}$ ) from Macherey-Nagel GmbH \& Co. KG (Düren, Germany) and a Dionex UltiMate $^{\mathrm{TM}} 3000$ UHPLC system (Thermo Fisher Scientific Inc., Waltham, MA, USA).

The mobile phase consisted of water (A) and acetonitrile (B), each with $0.1 \%$ formic acid. Gradient elution was performed in several steps, starting at $97 \%$ A for $5 \mathrm{~min}$, decreasing linearly to $80 \% \mathrm{~A}$ in $10 \mathrm{~min}$, and kept constant for $5 \mathrm{~min}$. Subsequently, there was a further reduction in mobile phase A to $70 \% \mathrm{~A}$ in $5 \mathrm{~min}$, followed by a plateau for $5 \mathrm{~min}$ and a final decrease to $30 \% \mathrm{~A}$ in $10 \mathrm{~min}$, which was held constant for $6 \mathrm{~min}$. The gradient was returned to $97 \% \mathrm{~A}$ in $4 \mathrm{~min}$, followed by a $15 \mathrm{~min}$ re-equilibration.

The injection volume was $10 \mu \mathrm{L}$ at a flow rate of $200 \mu \mathrm{L} / \mathrm{min}$ for all samples. The LC-MS system was controlled by HyStar 3.2 (Bruker Daltonik GmbH, Bremen, Germany).

Detection of the previously chromatographically separated tryptic untreated and BITCmodified protein hydrolysates was performed using an ESI-MS ion trap mass analyzer in positive ion mode (amazon speed ETD, Bruker Daltonik GmbH, Bremen, Germany) with the following settings analyzed: ion spray voltage: $4.5 \mathrm{kV}$; ion source heating: $350{ }^{\circ} \mathrm{C}$; source gas: 55 psi. Using the UniProtKB database (http:/ / www.uniprot.org/; accessed on 20 September 2021) and the SIB Bioinformatics Resource Portal ExPASy (https:/ / www. expasy.org/; accessed on 20 September 2021), the experimentally obtained data could be compared with a theoretical digest of $\alpha$-LA so that the obtained signals could be assigned and the resulting peptides could be identified.

\section{Conclusions}

In summary, it was shown that with increasing input concentration of BITC, an increasing degree of derivatization could be achieved, which was accompanied by a successive change in the secondary structure of $\alpha$-LA (loss of $\alpha$-helix moieties, with a concomitant increase in $\beta$-sheet moieties). The restructuring was related to the increased surface hydrophobicity because the change of the secondary structure was assumed to expose more hydrophobic regions on the protein surface. Accordingly, the change in protein structure resulting from BITC conjugation may have exposed hydrophobic regions (increase in surface hydrophobicity). This further enables hydrophobic interactions between multiple protein molecules, leading to larger $\alpha$-LA complexes/aggregates (increase in hydrodynamic radius) $[129,151]$, which could potentially be promoted via surface-exposed $B$-sheet structure. This assumption could explain the increase in hydrodynamic radius due to BITC modification. In addition, the mass spectrometric analysis revealed that as a result of BITC modification, the tryptic digestibility of $\alpha$-LA was decreased, which was attributed to steric blocking of the tryptic cleavage sites and the two modified amino acids that were located at the lysine side chains (K32 and K113) in the amino acid sequence of $\alpha$-LA.

These studies are of particular importance in order to assess the influence of chemical modifications on the molecular structure of proteins since structural changes can alter the functional and biological properties of proteins $[48,49,72,75,76]$. Furthermore, the determination of freely available amino groups plays a crucial role with regard to the properties and functionality of proteins [1,152]. Knowledge of the influence of chemical modifications on protein structure and surface hydrophobicity allows conclusions to be drawn about solubility, aggregation, and physical stability [52,153], which are particularly important with regard to food processing and food safety [1,51].

Author Contributions: Conceptualization, J.S., S.F. and S.R.; validation, J.S. and J.B.; formal analysis, J.S., J.B. and S.F.; investigation, J.S., J.B. and S.F.; resources, S.R.; writing-original draft preparation, J.S.; writing-review and editing, J.S., S.F. and S.R.; visualization, J.S.; supervision, S.R. All authors have read and agreed to the published version of the manuscript.

Funding: This research received no external funding.

Institutional Review Board Statement: Not applicable. 
Informed Consent Statement: Not applicable.

Data Availability Statement: The data presented in this study are available on request from the authors.

Conflicts of Interest: The authors declare no conflict of interest.

Sample Availability: Samples of the compounds are available from the authors.

\section{References}

1. Rade-Kukic, K.; Schmitt, C.; Rawel, H.M. Formation of conjugates between $\beta$-lactoglobulin and allyl isothiocyanate: Effect on protein heat aggregation, foaming and emulsifying properties. Food Hydrocoll. 2011, 25, 694-706. [CrossRef]

2. Sønderby, I.E.; Geu-Flores, F.; Halkier, B.A. Biosynthesis of glucosinolates-Gene discovery and beyond. Trends Plant Sci. 2010, 15, 283-290. [CrossRef]

3. Fernando, R.C.; Weiß-Schmidt, P. Sekundäre Pflanzenstoffe: Bioaktive substanzen aus obst und gemüse in der krebsprävention. EHK 2007, 56, 192-197. [CrossRef]

4. Herr, I.; Büchler, M. Glucosinolate der kreuzblütlerfamilie in prävention und therapie maligner tumore. Dtsch. Z. Onkol. 2009, 41, 109-114. [CrossRef]

5. Haller, D.; Grune, T.; Rimbach, G. Biofunktionalität der Lebensmittelinhaltsstoffe; Springer Spektrum: Berlin/Heidelberg, Germany, 2013; ISBN 9783642293733.

6. Kühn, C.; von Oesen, T.; Hanschen, F.S.; Rohn, S. Determination of isothiocyanate-protein conjugates in milk and curd after adding garden cress (Lepidium sativum L.). Food Res. Int. 2018, 108, 621-627. [CrossRef] [PubMed]

7. Keppler, J.K.; Koudelka, T.; Palani, K.; Tholey, A.; Schwarz, K. Interaction of -lactoglobulin with small hydrophobic ligandsInfluence of covalent AITC modification on -LG tryptic cleavage. Food Biophys. 2014, 9, 349-358. [CrossRef]

8. Juge, N.; Mithen, R.F.; Traka, M. Molecular basis for chemoprevention by sulforaphane: A comprehensive review. Cell. Mol. Life Sci. 2007, 64, 1105-1127. [CrossRef] [PubMed]

9. Keppler, J.K.; Martin, D.; Garamus, V.M.; Berton-Carabin, C.; Nipoti, E.; Coenye, T.; Schwarz, K. Functionality of whey proteins covalently modified by allyl isothiocyanate. Part 1 physicochemical and antibacterial properties of native and modified whey proteins at pH 2 to 7. Food Hydrocoll. 2017, 65, 130-143. [CrossRef]

10. Kühn, C.; Von Oesen, T.; Herz, C.; Schreiner, M.; Hanschen, F.S.; Lamy, E.; Rohn, S. In vitro determination of protein conjugates in human cells by LC-ESI-MS/MS after benzyl isothiocyanate exposure. J. Agric. Food Chem. 2018, 66, 6727-6733. [CrossRef] [PubMed]

11. Beevi, S.S.; Mangamoori, L.N.; Dhand, V.; Ramakrishna, D.S. Isothiocyanate profile and selective antibacterial activity of root, stem, and leaf extracts derived from Raphanus sativus L. Foodborne Pathog. Dis. 2009, 6, 129-136. [CrossRef]

12. Lee, Y.M.; Seon, M.R.; Cho, H.J.; Kim, J.S.; Park, J.H.Y. Benzyl isothiocyanate exhibits anti-inflammatory effects in murine macrophages and in mouse skin. J. Mol. Med. 2009, 87, 1251-1261. [CrossRef] [PubMed]

13. Sofrata, A.; Santangelo, E.M.; Azeem, M.; Borg-Karlson, A.K.; Gustafsson, A.; Pütsep, K. Benzyl isothiocyanate, a major component from the roots of Salvadora persica is highly active against gram-negative bacteria. PLoS ONE 2011, 6, e23045. [CrossRef] [PubMed]

14. Guzmán-Pérez, V.; Bumke-Vogt, C.; Schreiner, M.; Mewis, I.; Borchert, A.; Pfeiffer, A.F.H. Benzylglucosinolate derived isothiocyanate from Tropaeolum majus reduces gluconeogenic gene and protein expression in human cells. PLoS ONE 2016, 11, e162397. [CrossRef] [PubMed]

15. Kreis, W. Sekundäre Pflanzenstoffe und Krebs. Dtsch. Z. Onkol. 2009, 41, 100-108. [CrossRef]

16. Zhang, Y. Allyl isothiocyanate as a cancer chemopreventive phytochemical. Mol. Nutr. Food Res. 2010, 54, 127-135. [CrossRef]

17. Hanschen, F.S.; Lamy, E.; Schreiner, M.; Rohn, S. Reactivity and stability of glucosinolates and their breakdown products in foods. Angew. Chemie-Int. Ed. 2014, 53, 11430-11450. [CrossRef]

18. Cejpek, K.; Valusek, J.; Velisek, J. Reactions of allyl isothiocyanate with alanine, glycine, and several peptides in model systems. J. Agric. Food Chem. 2000, 48, 3560-3565. [CrossRef]

19. Hanschen, F.S.; Brüggemann, N.; Brodehl, A.; Mewis, I.; Schreiner, M.; Rohn, S.; Kroh, L.W. Characterization of products from the reaction of glucosinolate-derived isothiocyanates with cysteine and lysine derivatives formed in either model systems or broccoli sprouts. J. Agric. Food Chem. 2012, 60, 7735-7745. [CrossRef]

20. Zhang, Y.; Talalay, P. Anticarcinogenic activities of organic isothiocyanates: Chemistry and mechanisms. Cancer Res. 1994, $54,19761981$.

21. Keppler, J.K.; Martin, D.; Garamus, V.M.; Schwarz, K. Differences in binding behavior of (-)-epigallocatechin gallate to $\beta$ lactoglobulin heterodimers (AB) compared to homodimers (A) and (B). J. Mol. Recognit. 2015, 28, 656-666. [CrossRef]

22. Keppler, J.K.; Steffen-Heins, A.; Berton-Carabin, C.C.; Ropers, M.H.; Schwarz, K. Functionality of whey proteins covalently modified by allyl isothiocyanate. Part 2: Influence of the protein modification on the surface activity in an O/W system. Food Hydrocoll. 2018, 81, 286-299. [CrossRef]

23. Bock, A.; Steinhäuser, U.; Drusch, S. Partitioning behavior and interfacial activity of phenolic acid derivatives and their impact on $\beta$-lactoglobulin at the oil-water interface. Food Biophys. 2021, 16, 191-202. [CrossRef] 
24. Stanciuc, N.; Râpeanu, G. An overview of bovine a-lactalbumin structure and functionality. Ann. Univ. Dunarea Jos Galati-Fascicle VI-Food Technol. 2010, 34, 82-93.

25. Smithers, G.W. Whey and whey proteins-From "gutter-to-gold". Int. Dairy J. 2008, 18, 695-704. [CrossRef]

26. Smithers, G.W.; Ballard, F.J.; Copeland, A.D.; De Silva, K.J.; Dionysius, D.A.; Francis, G.L.; Goddard, C.; Grieve, P.A.; Mcintosh, G.H.; Mitchell, I.R.; et al. New Opportunities from the isolation and utilization of whey proteins. J. Dairy Sci. 1996, 79, 1454-1459. [CrossRef]

27. Kinsella, J.E. Milk proteins: Physicochemical and functional properties. CRC Crit. Rev. Food Sci. Nutr. 1984, 21, 197-262. [CrossRef]

28. Lam, R.S.H.; Nickerson, M.T. The effect of $\mathrm{pH}$ and temperature pre-treatments on the structure, surface characteristics and emulsifying properties of alpha-lactalbumin. Food Chem. 2015, 173, 163-170. [CrossRef] [PubMed]

29. Farrell, H.M.; Jimenez-Flores, R.; Bleck, G.T.; Brown, E.M.; Butler, J.E.; Creamer, L.K.; Hicks, C.L.; Hollar, C.M.; Ng-Kwai-Hang, K.F.; Swaisgood, H.E. Nomenclature of the proteins of cows' milk-Sixth revision. J. Dairy Sci. 2004, 87, 1641-1674. [CrossRef]

30. Kamau, S.M.; Cheison, S.C.; Chen, W.; Liu, X.M.; Lu, R.R. Alpha-lactalbumin: Its production technologies and bioactive peptides. Compr. Rev. Food Sci. Food Saf. 2010, 9, 197-212. [CrossRef]

31. Brew, K.; Castellino, F.J.; Vanaman, T.C.; Hill, R.L. The complete amino acid sequence of bovine alpha-lactalbumin. J. Biol. Chem. 1970, 245, 4570-4582. [CrossRef]

32. Permyakov, E.A.; Berliner, L.J. $\alpha$-lactalbumin: Structure and function. FEBS Lett. 2000, 473, 269-274. [CrossRef]

33. Bramaud, C.; Aimar, P.; Daufin, G. Thermal isoelectric precipitation of $\alpha$-lactalbumin from a whey protein concentrate: Influence of protein-calcium complexation. Biotechnol. Bioeng. 1995, 47, 121-130. [CrossRef]

34. Jackson, J.G.; Janszen, D.B.; Lonnerdal, B.; Lien, E.L.; Pramuk, K.P.; Kuhlman, C.F. A multinational study of $\alpha$-lactalbumin concentrations in human milk. J. Nutr. Biochem. 2004, 15, 517-521. [CrossRef]

35. Permyakov, E.A. $\alpha$-Lactalbumin, amazing calcium-binding protein. Biomolecules 2020, 10, 1210. [CrossRef]

36. Deeth, H.; Bansal, N. Whey Proteins; Elsevier Inc.: Amsterdam, The Netherlands, 2019; ISBN 9780128121245.

37. Jakopović, K.L.; Barukčić, I.; Božanić, R. Physiological significance, structure and isolation of $\alpha$-lactalbumin. Mljekarstvo 2016, 66, 3-11. [CrossRef]

38. Chang, J.Y.; Li, L. Pathway of oxidative folding of $\alpha$-lactalbumin: A model for illustrating the diversity of disulfide folding pathways. Biochemistry 2002, 41, 8405-8413. [CrossRef]

39. Rao, K.R.; Brew, K. Calcium regulates folding and disulfide-bond formation in $\alpha$-lactalbumin. Biochem. Biophys. Res. Commun. 1989, 163, 1390-1396. [CrossRef]

40. Pripp, A.H.; Vreeker, R.; Van Duynhoven, J. Binding of olive oil phenolics to food proteins. J. Sci. Food Agric. 2005, 85, 354-362. [CrossRef]

41. Katsuragi, Y.; Kashiwayanagi, M.; Kurihara, K. Specific inhibitor for bitter taste: Inhibition of frog taste nerve responses and human taste sensation to bitter stimuli. Brain Res. Protoc. 1997, 1, 292-298. [CrossRef]

42. Rawel, H.M.; Kroll, J.; Schröder, I. Reactions of isothiocyanates with food proteins: Influence on enzyme activity and tryptical degradation. Nahrung-Food 1998, 42, 197-199. [CrossRef]

43. Kroll, J.; Noack, J.; Rawel, H.; Kroeck, R.; Proll, J. Chemical reactions of benzyl isothiocyanate with egg-white protein fractions. J. Sci. Food Agric. 1994, 65, 337-345. [CrossRef]

44. Keppler, J.K.; Schwarz, K. Increasing the emulsifying capacity of whey proteins at acidic pH values through covalent modification with allyl isothiocyanate. Colloids Surf. A Physicochem. Eng. Asp. 2017, 522, 514-524. [CrossRef]

45. Kroll, J.; Rawel, H.; Kröck, R.; Proll, J.; Schnaak, W. Interactions of isothiocyanates with egg white proteins. Food Nahrung 1994, 38, 53-60. [CrossRef]

46. Rawel, H.; Kroll, J.; Haebel, S.; Peter, M. Reactions of a glucosinolate breakdown product (benzyl isothiocyanate) with myoglobin. Phytochemistry 1998, 48, 1305-1311. [CrossRef]

47. Spöttel, J.; Brockelt, J.; Badekow, S.; Rohn, S. Immunological analysis of isothiocyanate-modified $\alpha$-lactalbumin using highperformance thin layer chromatography. Molecules 2021, 26, 1842. [CrossRef]

48. Kelly, S.M.; Price, N.C. The application of circular dichroism to studies of protein folding and unfolding. Biochim. Biophys. Acta-Protein Struct. Mol. Enzymol. 1997, 1338, 161-185. [CrossRef]

49. Venyaminov, S.Y.; Yang, J.T. Determination of protein secondary structure. Circ. Dichroism Conform. Anal. Biomol. 1996, 69-107. [CrossRef]

50. Keppler, J.K.; Schwarz, K.; van der Goot, A.J. Covalent modification of food proteins by plant-based ingredients (polyphenols and organosulphur compounds): A commonplace reaction with novel utilization potential. Trends Food Sci. Technol. 2020, 101, 38-49. [CrossRef]

51. Sun, Q.; Gao, X.; Bi, H.; Xie, Y.; Tang, L. Assessment of binding interaction between bovine lactoferrin and tetracycline hydrochloride: Multi-spectroscopic analyses and molecular modeling. Molecules 2018, 23, 1900. [CrossRef]

52. Hawe, A.; Sutter, M.; Jiskoot, W. Extrinsic fluorescent dyes as tools for protein characterization. Pharm. Res. 2008, 25, 1487-1499. [CrossRef]

53. Acharya, P.; Rao, N.M. Stability studies on a lipase from Bacillus subtilis in guanidinium chloride. J. Protein Chem. 2003, 22, 51-60. [CrossRef] [PubMed]

54. Anraku, M.; Yamasaki, K.; Maruyama, T.; Kragh-Hansen, U.; Otagiri, M. Effect of oxidative stress on the structure and function of human serum albumin. Pharm. Res. 2001, 18, 632-639. [CrossRef] [PubMed] 
55. Goto, Y.; Fink, A.L. Conformational states of $\beta$-lactamase: Molten-globule states at acidic and alkaline $\mathrm{pH}$ with high salt. Biochemistry 1989, 28, 945-952. [CrossRef] [PubMed]

56. Cardamone, M.; Puri, N.K. Spectrofluorimetric assessment of the surface hydrophobicity of proteins. Biochem. J. 1992, 282, 589-593. [CrossRef] [PubMed]

57. Qadeer, A.; Rabbani, G.; Zaidi, N.; Ahmad, E.; Khan, J.M.; Khan, R.H. 1-Anilino-8-Naphthalene Sulfonate (ANS) Is not a desirable probe for determining the molten globule state of chymopapain. PLoS ONE 2012, 7, e50633. [CrossRef]

58. Alizadeh-Pasdar, N.; Li-Chan, E.C.Y. Comparison of protein surface hydrophobicity measured at various $\mathrm{pH}$ values using three different fluorescent probes. J. Agric. Food Chem. 2000, 48, 328-334. [CrossRef] [PubMed]

59. Hayakawa, S.; Nakai, S. Relationships of hydrophobicity and net charge to the solubility of milk and soy proteins. J. Food Sci. 1985, 50, 486-491. [CrossRef]

60. Gerbanowski, A.; Malabat, C.; Rabiller, C.; Guéguen, J. Grafting of aliphatic and aromatic probes on rapeseed 2S and 12S proteins: Influence on their structural and physicochemical properties. J. Agric. Food Chem. 1999, 47, 5218-5226. [CrossRef]

61. Lottspeich, F.; Engels, J. Bioanalytik; Spektrum Academischer: Heidelberg, Germany, 2012.

62. Biemann, K. Mass spectrometry of peptides and proteins. Annu. Rev. Biochem. 1992, 61, 977-1010. [CrossRef]

63. Roepstorff, P.; Fohlman, P. Proposal for a common nomenclature for sequence ions in mass spectra of peptides. Biomed. Mass Spectrom. 1984, 11, 601. [CrossRef]

64. Keppler, J.K.; Koudelka, T.; Palani, K.; Stuhldreier, M.C.; Temps, F.; Tholey, A.; Schwarz, K. Characterization of the covalent binding of allyl isothiocyanate to $\beta$-lactoglobulin by fluorescence quenching, equilibrium measurement, and mass spectrometry. J. Biomol. Struct. Dyn. 2014, 32, 1103-1117. [CrossRef] [PubMed]

65. Keppler, J.K.; Sönnichsen, F.D.; Lorenzen, P.C.; Schwarz, K. Differences in heat stability and ligand binding among $\beta$-lactoglobulin genetic variants A, B and C using 1H NMR and fluorescence quenching. Biochim. Biophys. Acta-Proteins Proteomics 2014, 1844, 1083-1093. [CrossRef] [PubMed]

66. Kroll, J.; Rawel, H.; Kröck, R.; Schnaak, W. Interaction of benzyl isothiocyanate with egg white proteins. Food/Nahrung 1993, 37, 179-181. [CrossRef]

67. Kroll, J.; Rawel, H. Chemical reactions of benzyl isothiocyanate with myoglobin. J. Sci. Food Agric. 1996, 72, 376-384. [CrossRef]

68. Kawakishi, S.; Kaneko, T. Interaction of proteins with allyl isothiocyanate. J. Agric. Food Chem. 1987, 35, 85-88. [CrossRef]

69. Rawel, H.M.; Kroll, J. Some aspects of reactions of benzyl isothiocyanate with bovine sarcoplasmic proteins. Food Nahrung 1995, 39, 465-474. [CrossRef]

70. Rutherfurd, S.M. Food Composition and additives: Methodology for determining degree of hydrolysis of proteins in hydrolysates: A review. J. AOAC Int. 2010, 93, 1-8. [CrossRef]

71. Kishore Kumar Murthy, N.V.; Narasinga Rao, M.S. Interaction of allyl isothiocyanate with mustard 12S Protein. J. Agric. Food Chem. 1986, 34, 448-452. [CrossRef]

72. Woody, R.W. Circular dichroism. Methods Enzymol. 1995, 246, 34-71. [CrossRef]

73. Kelly, S.M.; Jess, T.J.; Price, N.C. How to study proteins by circular dichroism. Biochim. Biophys. Acta-Proteins Proteomics 2005, 1751, 119-139. [CrossRef] [PubMed]

74. Drake, A.F. Polarisation modulation-The measurement of linear and circular dichroism. J. Phys. Sci. Instrum. 1986, 19, 170-181. [CrossRef]

75. Bulheller, B.M.; Rodger, A.; Hirst, J.D. Circular and linear dichroism of proteins. Phys. Chem. Chem. Phys. 2007, 9, 2020-2035. [CrossRef] [PubMed]

76. Whitmore, L.; Wallace, B.A. Protein secondary structure analyses from circular dichroism spectroscopy: Methods and reference databases. Biopolymers 2008, 89, 392-400. [CrossRef] [PubMed]

77. Moriyama, Y.; Ohta, D.; Hachiya, K.; Mitsui, Y.; Takeda, K. Fluorescence behavior of tryptophan residues of bovine and human serum albumins in ionic surfactant solutions: A comparative study of the two and one tryptophan(s) of bovine and human albumins. J. Protein Chem. 1996, 15, 265-272. [CrossRef]

78. Moriyama, Y.; Takeda, K. Protective effects of small amounts of bis(2-ethylhexyl)sulfosuccinate on the helical structures of human and bovine serum albumins in their thermal denaturations. Langmuir 2005, 21, 5524-5528. [CrossRef] [PubMed]

79. Moriyama, Y.; Takeda, K. Re-formation of the helical structure of human serum albumin by the addition of small amounts of sodium dodecyl sulfate after the disruption of the structure by urea. A comparison with bovine serum albumin. Langmuir 1999, 15, 2003-2008. [CrossRef]

80. Parker, W.; Song, P.S. Protein structures in SDS micelle-protein complexes. Biophys. J. 1992, 61, 1435-1439. [CrossRef]

81. Alcala, J.R.; Gratton, E.; Prendergast, F.G. Interpretation of fluorescence decays in proteins using continuous lifetime distributions. Biophys. J. 1987, 51, 925-936. [CrossRef]

82. Santra, M.K.; Banerjee, A.; Rahaman, O.; Panda, D. Unfolding pathways of human serum albumin: Evidence for sequential unfolding and folding of its three domains. Int. J. Biol. Macromol. 2005, 37, 200-204. [CrossRef]

83. Moriyama, Y.; Kawasaka, Y.; Takeda, K. Protective effect of small amounts of sodium dodecyl sulfate on the helical structure of bovine serum albumin in thermal denaturation. J. Colloid Interface Sci. 2003, 257, 41-46. [CrossRef]

84. Sreerama, N.; Venyaminov, S.Y.; Woody, R.W. Estimation of protein secondary structure from circular dichroism spectra: Inclusion of denatured proteins with native proteins in the analysis. Anal. Biochem. 2000, 287, 243-251. [CrossRef] [PubMed] 
85. Corrêa, D.; Ramos, C. The use of circular dichroism spectroscopy to study protein folding, form and function. Afr. J. Biochem. Res. 2009, 3, 164-173.

86. Greenfield, N.J. Using circular dichroism spectra to estimate protein secondary structure. Nat. Protoc. 2007, 1, 2876-2890. [CrossRef] [PubMed]

87. Sreerama, N.; Woody, R.W. Computation and analysis of protein circular dichroism spectra. Methods Enzymol. 2004, 383, 318-351. [CrossRef]

88. Johnson, W.C. Protein secondary structure and circular dichroism: A practical guide. Proteins Struct. Funct. Bioinform. 1990, 7, 205-214. [CrossRef]

89. Chen, Y.-H.; Yang, J.; Chau, K. Determination of the helix and $\beta$ form of proteins in aqueous solution by circular dichroism. Biochemistry 1974, 13, 3350-3359. [CrossRef]

90. Wei, Y.; Thyparambil, A.A.; Latour, R.A. Protein helical structure determination using CD spectroscopy for solutions with strong background absorbance from 190 to $230 \mathrm{~nm}$. Biochim. Biophys. Acta-Proteins Proteom. 2014, 1844, 2331-2337. [CrossRef]

91. Rawel, H.M.; Rohn, S.; Kruse, H.P.; Kroll, J. Structural changes induced in bovine serum albumin by covalent attachment of chlorogeanic acid. Food Chem. 2002, 78, 443-455. [CrossRef]

92. Polverino de Laureto, P.; Frare, E.; Gottardo, R.; van Dael, H.; Fontana, A. Partly folded states of members of the lysozyme/lactalbumin superfamily: A comparative study by circular dichroism spectroscopy and limited proteolysis. Protein Sci. 2002, 11, 2932-2946. [CrossRef]

93. Brew, K. $\alpha$-Lactalbumin. In Advanced Dairy Chemistry_Proteins; Fox, P.F., McSweeney, P.L.H., Eds.; Springer: Boston, MA, USA, 2003; pp. 387-419.

94. Acharya, K.R.; Stuart, D.I.; Walker, N.P.C.; Lewis, M.; Phillips, D.C. Refined structure of baboon $\alpha$-lactalbumin at $1.7 \AA$ A resolution. Comparison with C-type lysozyme. J. Mol. Biol. 1989, 208, 99-127. [CrossRef]

95. Delavari, B.; Saboury, A.A.; Atri, M.S.; Ghasemi, A.; Bigdeli, B.; Khammari, A.; Maghami, P.; Moosavi-Movahedi, A.A.; Haertlé, T.; Goliaei, B. Alpha-lactalbumin: A new carrier for vitamin D3 food enrichment. Food Hydrocoll. 2015, 45, 124-131. [CrossRef]

96. Pike, A.C.W.; Brew, K.; Acharya, K.R. Crystal structures of guinea-pig, goat and bovine $\alpha$-lactalbumin highlight the enhanced conformational flexibility of regions that are significant for its action in lactose synthase. Structure 1996, 4, 691-703. [CrossRef]

97. Chrysina, E.D.; Brew, K.; Acharya, K.R. Crystal structures of Apo- and holo-bovine $\alpha$-lactalbumin at 2.2- $\AA$ resolution reveal an effect of calcium on inter-lobe interactions. J. Biol. Chem. 2000, 275, 37021-37029. [CrossRef]

98. Boggione Santos, I.J.; Hernandez Hernandez, H.L.; Cardoso Costa, M.H.; de Queiroz Lafetá, J.A.; dos Reis Coimbra, J.S. Conjugates of $\alpha$-lactalbumin, $\beta$-lactoglobulin, and lysozyme with polysaccharides: Characterization and techno-functional properties. Food Res. Int. 2019, 116, 492-498. [CrossRef]

99. Wilde, S.C.; Treitz, C.; Keppler, J.K.; Koudelka, T.; Palani, K.; Tholey, A.; Rawel, H.M.; Schwarz, K. $\beta$-Lactoglobulin as nanotransporter-Part II: Characterization of the covalent protein modification by allicin and diallyl disulfide. Food Chem. 2016, 197, 1022-1029. [CrossRef]

100. Wu, X.; Dey, R.; Wu, H.; Liu, Z.; He, Q.; Zeng, X. Studies on the interaction of -epigallocatechin-3-gallate from green tea with bovine $\beta$-lactoglobulin by spectroscopic methods and docking. Int. J. Dairy Technol. 2013, 66, 7-13. [CrossRef]

101. Wu, X.; Liu, M.; Xia, L.; Wu, H.; Liu, Z.; Xu, X. Conjugation of functional oligosaccharides reduced in vitro allergenicity of $\beta$-lactoglobulin. Food Agric. Immunol. 2013, 24, 379-391. [CrossRef]

102. Das, A.; Thakur, R.; Dagar, A.; Chakraborty, A. A spectroscopic investigation and molecular docking study on the interaction of hen egg white lysozyme with liposomes of saturated and unsaturated phosphocholines probed by an anticancer drug ellipticine. Phys. Chem. Chem. Phys. 2014, 16, 5368-5381. [CrossRef] [PubMed]

103. Schwenke, K.D.; Knopfe, C.; Seifert, A.; Görnitz, E.; Zirwer, D. Acetylation of faba bean legumin: Conformational changes and aggregation. J. Sci. Food Agric. 2001, 81, 126-134. [CrossRef]

104. Rawel, H.M.; Rohn, S.; Kroll, J. Influence of a sugar moiety (rhamnosylglucoside) at 3-O position on the reactivity of quercetin with whey proteins. Int. J. Biol. Macromol. 2003, 32, 109-120. [CrossRef]

105. Anand, U.; Jash, C.; Mukherjee, S. Protein unfolding and subsequent refolding: A spectroscopic investigation. Phys. Chem. Chem. Phys. 2011, 13, 20418-20426. [CrossRef]

106. Fang, Y.; Dalgleish, D.G. The conformation of $\alpha$-lactalbumin as a function of $\mathrm{pH}$, heat treatment and adsorption at hydrophobic surfaces studied by FTIR. Food Hydrocoll. 1998, 12, 121-126. [CrossRef]

107. Kelly, S.; Price, N. The Use of Circular Dichroism in the Investigation of Protein Structure and Function. Curr. Protein Pept. Sci. 2005, 1, 349-384. [CrossRef]

108. Walters, J.; Milam, S.L.; Clark, A.C. Chapter 1 Practical Approaches to Protein Folding and Assembly. Spectroscopic Strategies in Thermodynamics and Kinetics; Elsevier Inc.: Amsterdam, The Netherlands, 2009; ISBN 9780123745965.

109. Semisotnov, G.V.; Rodionova, N.A.; Razgulyaev, O.I.; Uversky, V.N.; Gripas', A.F.; Gilmanshin, R.I. Study of the "molten globule" intermediate state in protein folding by a hydrophobic fluorescent probe. Biopolymers 1991, 31, 119-128. [CrossRef]

110. Stryer, L. The interaction of a naphthalene dye with apomyoglobin and apohemoglobin: A fluorescent probe of non-polar binding sites. J. Mol. Biol. 1965, 13, 482-495. [CrossRef]

111. Gasymov, O.K.; Glasgow, B.J. ANS fluorescence: Potential to augment the identification of the external binding sites of proteins. Biochim. Biophys. Acta-Proteins Proteom. 2007, 1774, 403-411. [CrossRef] 
112. Slavík, J. Anilinonaphthalene sulfonate as a probe of membrane composition and function. Biochim. Biophys. Acta 1982, 694, 1-25. [CrossRef]

113. Tanford, C. The Hydrophobic Effect: Formation of micelles and biological membranes. FEBS Lett. 1981, 124, 127. [CrossRef]

114. Singh, S.K.; Kishore, N. Elucidating the Binding Thermodynamics of 8-Anilino-1-Naphthalene Sulfonic Acid with the A-State of a-Lactalbumin: An Isothermal Titration Calorimetric Investigation. Biopolymers 2006, 83, 205-212. [CrossRef] [PubMed]

115. Asthana, S.; Bhutia, S.K.; Sahoo, H.; Jha, S. Chaotropes trigger conformational rearrangements differently in Concanavalin A. J. Chem. Sci. 2017, 129, 1267-1276. [CrossRef]

116. Li, T.; Wang, C.; Li, T.; Ma, L.; Sun, D.; Hou, J.; Jiang, Z. Surface hydrophobicity and functional properties of citric acid cross-linked whey protein isolate: The impact of $\mathrm{pH}$ and concentration of citric acid. Molecules 2018, 23, 2383. [CrossRef] [PubMed]

117. Lakkis, J.; Villota, R. Effect of acylation on substructural properties of proteins: A study using fluorescence and circular dichroism. J. Agric. Food Chem. 1992, 40, 553-560. [CrossRef]

118. Kato, A.; Nakai, S. Hydrophobicity determined by a fluorescence probe method and its correlation with surface properties of proteins. Biochim. Biophys. Acta 1980, 624, 13-20. [CrossRef]

119. Kroll, J.; Rawel, H.M.; Seidelmann, N. Physicochemical properties and susceptibility to proteolytic digestion of myoglobin-phenol derivatives. J. Agric. Food Chem. 2000, 48, 1580-1587. [CrossRef]

120. Rawel, H.M.; Kroll, J.; Hohl, U.C. Model studies on reactions of plant phenols with whey proteins. Nahrung-Food 2001, 45, 72-81. [CrossRef]

121. Goldburg, W.I. Dynamic light scattering. Am. J. Phys 1999, 67, 1152-1160. [CrossRef]

122. Lorber, B.; Fischer, F.; Bailly, M.; Roy, H.; Kern, D. Protein analysis by dynamic light scattering: Methods and techniques for students. Biochem. Mol. Biol. Educ. 2012, 40, 372-382. [CrossRef]

123. Sandhu, R.; Singh, N.; Dhankhar, J.; Kama, G.; Sharma, R. Dynamic light scattering (DLS) technique, principle, theoretical considerations and applications. Nanotechnol. Biochem. Tech. Assess. Qual. Saf. Milk Milk Prod. 2018, pp. 135-137. Available online: https:/ / www.researchgate.net/publication/331022012 (accessed on 14 October 2021).

124. Harding, S.; Jumel, K. Analysis of Proteins. Curr. Protoc. Mol. Biol. 1998, 44, 1-14. [CrossRef]

125. Harding, S.E. Protein Hydrodynamics; Allen, G., Ed.; JAI Press Inc.: Greenwich, CT, USA, 1999; ISBN 9781559386722.

126. Kehoe, J.J.; Brodkorb, A. Interactions between sodium oleate and $\alpha$-lactalbumin: The effect of temperature and concentration on complex formation. Food Hydrocoll. 2014, 34, 217-226. [CrossRef]

127. Kataoka, M.; Kuwajima, K.; Tokunaga, F.; Goto, Y. Structural characterization of the molten globule of $\alpha$-lactalbumin by solution X-ray scattering. Protein Sci. 1997, 6, 422-430. [CrossRef]

128. Abbasi, A.; Emam-Djomeh, Z.; Mousavi, M.A.E.; Davoodi, D. Stability of vitamin D3 encapsulated in nanoparticles of whey protein isolate. Food Chem. 2014, 143, 379-383. [CrossRef]

129. Lin, F.Y.; Chen, W.Y.; Ruaan, R.C.; Huang, H.M. Microcalorimetric studies of interactions between protein and hydrophobic ligands in hydrophobic interaction chromatography: Effects of ligand chain length, density, and the amount of bound protein. Prog. Biotechnol. 2000, 16, 59-62. [CrossRef]

130. Hoffmann, M.A.M.; Sala, G.; Olieman, C.; De Kruif, K.G. Molecular mass distributions of heat-induced $\beta$-lactoglobulin aggregates. J. Agric. Food Chem. 1997, 45, 2949-2957. [CrossRef]

131. Barth, H. Modern Methods of Particle Size Analysi; Wiley: New York, NY, USA, 1984.

132. Olsen, J.V.; Ong, S.E.; Mann, M. Trypsin cleaves exclusively C-terminal to arginine and lysine residues. Mol. Cell. Proteomics 2004, 3, 608-614. [CrossRef]

133. Rawel, H.M.; Kroll, J.; Schröder, I. In vitro enzymatic digestion of benzyl- and phenylisothiocyanate-derivatized food proteins. J. Agric. Food Chem. 1998, 46, 5103-5109. [CrossRef]

134. Chevalier, F.; Chobert, J.; Molle, D.; Haertle, T. Maillard glycation of ß-lactoglobulin with several sugars: Comparative study of the properties of the obtained polymers and of the substituted sites. Lait 2001, 81, 651-666. [CrossRef]

135. Chevalier, F.; Chobert, J.M.; Dalgalarrondo, M.; Haertlé, T. Characterization of the Maillard reaction products of $\beta$-lactoglobulin glucosylated in mild conditions. J. Food Biochem. 2001, 25, 33-55. [CrossRef]

136. Syka, J.E.P.; Coon, J.J.; Schroeder, M.J.; Shabanowitz, J.; Hunt, D.F. Peptide and protein sequence analysis by electron transfer dissociation mass spectrometry. Proc. Natl. Acad. Sci. USA 2004, 101, 9528-9533. [CrossRef] [PubMed]

137. Bertran-Vicente, J.; Schümann, M.; Hackenberger, C.P.R.; Krause, E. Gas-phase rearrangement in lysine phosphorylated peptides during electron-transfer dissociation tandem mass spectrometry. Anal. Chem. 2015, 87, 6990-6994. [CrossRef]

138. Hernández, M.J.M.; Domingo, E.B.; Camañas, R.M.V.; Alvarez-Coque, M.C.G. Evaluation of the proteolysis degree with the o-phthalaldehyde/N-acetyl-L-cysteine reagent. Fresenius. J. Anal. Chem. 1990, 338, 62-65. [CrossRef]

139. García Alvarez-Coque, M.C.; Medina Hernández, M.J.; Villanueva Camañas, R.M.; Mongay Fernández, C. Formation and instability of o-phthalaldehyde derivatives of amino acids. Anal. Biochem. 1989, 178, 1-7. [CrossRef]

140. Hernández, M.J.M.; Camañas, R.M.V.; Cuenca, E.M.; Alvarez-Coque, M.C.G. Determination of the protein and free amino acid content in a sample using o-phthalaldehyde and N-acetyl-L-CYSTEINE. Analyst 1990, 115, 1125-1128. [CrossRef]

141. Spellman, D.; McEvoy, E.; O'Cuinn, G.; FitzGerald, R.J. Proteinase and exopeptidase hydrolysis of whey protein: Comparison of the TNBS, OPA and pH stat methods for quantification of degree of hydrolysis. Int. Dairy J. 2003, 13, 447-453. [CrossRef]

142. Hernández, M.J.M.; Domingo, E.B.; Camañas, R.M.V.; Alvarez-Coque, M.C.G. Use of the o-Phthalaldehyde and N-Acetyl-LCysteine the Evaluation of Milk Proteins. J. Dairy Sci. 1991, 74, 1779-1785. [CrossRef] 
143. Goodno, C.C.; Swaisgood, H.E.; Catignani, G.L. A fluorimetric assay for available lysine in proteins. Anal. Biochem. 1981, 115, 203-211. [CrossRef]

144. Roth, M. Fluorescence Reaction for Amino Acids. Anal. Chem. 1971, 43, 880-882. [CrossRef]

145. Interchim. In OPA, Amine Detection Reagent; Interchim: Montlucon, France, 2016; pp. 10-12. Available online: https://www. interchim.fr/ft/0/02727A.pdf (accessed on 14 October 2021).

146. Andrade, M.A.; Chacón, P.; Merelo, J.J.; Morán, F. Evaluation of secondary structure of proteins from uv circular dichroism spectra using an unsupervised learning neural network. Protein Eng. Des. Sel. 1993, 6, 383-390. [CrossRef] [PubMed]

147. Whitmore, L.; Wallace, B.A. DICHROWEB, an online server for protein secondary structure analyses from circular dichroism spectroscopic data. Nucleic Acids Res. 2004, 32, 668-673. [CrossRef] [PubMed]

148. Takehara, K.; Yuki, K.; Shirasawa, M.; Yamasaki, S.; Yamada, S. Binding Properties of Hydrophobic Molecules to Human Serum Albumin Studied by Fluorescence Titration. Anal. Sci. 2009, 25, 115-120. [CrossRef] [PubMed]

149. Lam, R.S.H.; Nickerson, M.T. The effect of $\mathrm{pH}$ and temperature pre-treatments on the physicochemical and emulsifying properties of whey protein isolate. LWT-Food Sci. Technol. 2015, 60, 427-434. [CrossRef]

150. Hoffman, R.E.; Shabtai, E.; Rabinovitz, M.; Iyer, S.V.; Müllen, K.; Rai, A.K.; Bayrd, E.; Scott, L.T. Self-diffusion measurements of polycyclic aromatic hydrocarbon alkali metal salts. J. Chem. Soc. Perkin Trans. 1998, 2, 1659-1664. [CrossRef]

151. Roberts, C.J. Non-Native Protein Aggregation Kinetics Christopher. Biotechnol. Bioeng. 2007, 98, 927-938. [CrossRef] [PubMed]

152. Rutherfurd, S.M.; Moughan, P.J. Digestible reactive lysine in selected milk-based products. J. Dairy Sci. 2005, 88, 40-48. [CrossRef]

153. Soto, C.; Sigurdsson, E.M.; Morelli, L.; Asok Kumar, R.; Castaño, E.M.; Frangione, B. Solubility as funtion of proteins structure and solvent components. Nat. Med. 1998, 4, 822-826. [CrossRef] [PubMed] 